in Human Behavior

Manuscript Number: CHB-D-16-00756R1

Title: Modelling Continuance Intention of Citizens in Government Facebook Page: A Complementary PLS Approach

Article Type: Full Length Article

Section/Category: Full Length Article

Keywords: Continuance intention, Facebook page, electronic government, expectation confirmation, information system success, PLS-SEM

Corresponding Author: Dr. Naser Valaei, Ph.D.

Corresponding Author's Institution: Sunway University

First Author: Naser Valaei, Ph.D.

Order of Authors: Naser Valaei, Ph.D.; Mas Bambang Baroto, Associate Professor

Abstract: The main purpose of this paper is to examine the continuance intention (CI) of citizens in following government Facebook page. Applying theories of expectation-confirmation, and information system success on a sample of 362 students in Malaysia, and using Partial Least Squares-Structural Equation Modelling (PLS-SEM), the study finds that CI and satisfaction of government Facebook page is contingent upon information quality (IQ) of the Facebook page per se. IQ is found as a second order construct of five first order factors: reliability, completeness, relevancy, timeliness, and understandability. Satisfaction of government Facebook page is also found as a partial mediator to the relationship between IQ and CI of following government Facebook page. In addition, applying PLS multi-group analysis, the results show that different government Facebook pages moderate the relationships between IQ and satisfaction of government Facebook page, IQ and CI of following government Facebook page as well as satisfaction of government Facebook page and CI of following government Facebook page. 


\title{
Modelling Continuance Intention of Citizens in Government Facebook Page: A Complementary PLS Approach
}

\begin{abstract}
The main purpose of this paper is to examine the continuance intention (CI) of citizens in following government Facebook page. Applying theories of expectation-confirmation, and information system success on a sample of 362 students in Malaysia, and using Partial Least Squares-Structural Equation Modelling (PLS-SEM), the study finds that CI and satisfaction of government Facebook page is contingent upon information quality (IQ) of the Facebook page per se. IQ is found as a second order construct of five first order factors: reliability, completeness, relevancy, timeliness, and understandability. Satisfaction of government Facebook page is also found as a partial mediator to the relationship between IQ and CI of following government Facebook page. In addition, applying PLS multi-group analysis, the results show that different government Facebook pages moderate the relationships between IQ and satisfaction of government Facebook page, IQ and CI of following government Facebook page as well as satisfaction of government Facebook page and CI of following government Facebook page.
\end{abstract}

Keywords: Continuance intention, Facebook page, electronic government, expectation confirmation, information system success, PLS-SEM

\section{Introduction}

Advent of Internet and increased accessibility of Smartphone devises has enabled new wage of interaction and it has substantially influenced the traditional style of living. Its omnipresence has impacted human life in all aspects from the way he or she behaves toward business, finance, society, and politics. Transformation of Web 1.0 to Web 2.0 technologies has facilitated information sharing, collaboration, and interoperability. The main technology of Web 2.0 is social networking websites. More than a billion people have joined social media websites mainly Facebook due to high collaboration and facilitation of user-generated content.

Nowadays, Internet users favour dynamic informative websites within which the users can express their beliefs and comment on the service, product, and particular news or events. 
Traditional websites lack such capabilities due to their static nature and such websites are deficient in producing enough value for users to be involved in long-term activities (Bettoni, Andenmatten, \& Mathieu, 2007). This is one of the main reasons that Internet users prefer to obtain their information from social networking sites such as Facebook or Twitter and they no longer refer to the traditional website of a company or organization but rather their Facebook/Twitter pages. Facebook pages are accessible through a myriad of platforms such as desktop computers, laptops, tablets, smartphones, as well as different software such as apps and browsers.

Several giant companies and organizations have made their Facebook pages for advertising and informative purposes. Cumbie and Kar (2014) indicate that lack of inclusiveness is one of issues local e-government websites face in United States. They mention widespread absence of government websites, high number of issues geared with developed government websites, as well as high frequency of issues of each government website as a restrain for e-government inclusiveness. In addition, citizens are shifting their channel choice preferences (Reddick, Abdelsalam, \& Elkadi, 2012) from traditional channels to e-government. Facebook pages represent a challenge for political organizations (Nitschke, Donges, \& Schade, 2016). These facts could be reasons why governmental organizations are developing their Facebook pages to provide up-to-date information and observe the user feedbacks about policies and regulations posed by government. Due to high usage of Facebook website, a governmental page can be a good medium of interaction between citizens and agencies. Therefore, examining the CI of Facebook users is important and it has become a key research issue in information systems (IS) field of study (Al-Debei, Al-Lozi, \& Papazafeiropoulou, 2013).

Nowadays, the world of communication is moving from dialogue to trialogue where Facebook pages act as "echo chambers" of communication (Grömping, 2014). Facebook pages are the headwaters of mass media (L. C. S. Lin, 2016). Facebook provides an inexpensive and attractive means of citizen outreach for local governments. It has potential for promoting participatory democracy and people use Facebook to engage in political campaigns (Gulati \& Williams, 2013). The importance of social network site is evident in such a way that Facebook pages are utilized to mobilize an online movement that moves offline (Harlow, 2012). However, governments need to be vigilant in their online presence and information provision, as the digital media bypass the traditional media.

Research about using social media in government is limited (Haro-de-Rosario, SáezMartín, \& Caba-Pérez, In Press); yet, hitherto few research has empirically investigated 
government Facebook pages. In BP's Deepwater Horizon oil spill (Ye \& Ki, 2017) and Fukushima nuclear disaster (Tampere, Tampere, \& Luoma-Aho, 2016), information giving strategy on Facebook page was shown to be the most effective crisis response strategy. However, government agencies can learn from such cases to understand the importance of information provision. But, the question still remains: what IQ criteria are required in government Facebook pages?

Local governments use Facebook for organizational learning purposes from interactions with citizens (Reddick, Chatfield, \& Ojo, In Press). Reddick, et al. (In Press) quote that "the problem that local governments face is finding best ways to harness new digital social media platforms and make meaningful changes to public service delivery through citizen feedback". Current research aims to address this problem by proposing that IQ of government Facebook pages improve citizen feedback, their level of satisfaction, and CI to follow Facebook pages.

Furthermore, studies on Facebook are mainly based on samples in US and research is required in other countries with different settings (Caers, et al., 2013). Since study shows that Facebook is preferred to Twitter by citizens in their relations with local government (Harode-Rosario, et al., In Press), understanding CI of citizens in Facebook pages contributes significantly to the body of knowledge in the social media context. In addition, research lacks on the users' perception of organizational Facebook pages (Caers, et al., 2013). Therefore, this research sheds light on the extent to which citizens perceive government-driven communication on government Facebook pages in a developing and multicultural country, Malaysia.

Investigating the factors participating in CI of government Facebook pages is critical for governmental agencies to sustain the proper operation of their pages, engagement of their users, and feedbacks of their rules and regulations they pose. This paper is aimed to tap into the CI of government Facebook page and examine what is the user perception of IQ and the extent to which it is related to user satisfaction and CI of government Facebook page. This study proposes a theoretical framework based on theories of IS success (DeLone \& McLean, 1992) and expectation-confirmation (Oliver, 1980) and develops 6 hypotheses. Following sections delve into the theories and links between the related concepts through reviewing the literature on IQ, satisfaction, CI, and government Facebook pages.

\section{Literature review}




\subsection{Government Facebook Page Information Quality}

An extensive search through leading journals and online databases revealed that previous research has not tapped into government Facebook page service quality. Evaluating Facebook page service quality resonates the IQ of government page because most users are information seekers. IQ has become a vital issue for organizations and companies because variety of systems and people access information directly and there is a need for considering a high standard for IQ (Y. W. Lee, Strong, Kahn, \& Wang, 2002). Research on IQ has been enormously conducted to examine the needs of organizations regarding this matter (Batini, Catarci, \& Scannapiceco, 2004; Bilenko \& Mooney, 2003). The capability to assess the quality of information is needed for organizations to monitor their success and improvement regarding IQ. This may happen through developing a model for IQ measurement and assessment or through benchmarking.

Y. W. Lee, et al. (2002) categorize dimensions of IQ as intrinsic, contextual, and representational IQ. Intrinsic IQ refers to the inherent quality of information. Researchers have given different attributes to intrinsic IQ. For instance, accuracy, believability, reputation, objectivity (Monge, 2000), factual (Naumann, Leser, \& Freytag, 1999), credibility, consistency, completeness (De Giacomo, Lembo, Lenzerini, \& Rosati, 2004), precision, reliability, freedom from bios (Celko \& McDonald, 1995), correctness, and unambiguous (Mihaila, Raschid, \& Vidal, 2000) are considered as characteristics of intrinsic IQ. Amongst these characteristics, accuracy, reliability, and consistency are examined as main attributes of intrinsic IQ.

Contextual IQ refers to the context relatedness and its appropriateness for the task at hand (Y. W. Lee, et al., 2002). Value added, timeliness, relevance, completeness (Monge, 2000), quantity, reliable (Naumann, et al., 1999), usage, source currency, data warehouse currency (De Giacomo, et al., 2004), usefulness, informative, and sufficiency (Celko \& McDonald, 1995) are other attributes of contextual IQ. Amongst these attributes, currency, completeness, timeliness, and relevance are considered as main characteristics of contextual IQ (Batini, et al., 2004; Mihaila, et al., 2000).

Representational IQ refers to the characteristics of computer systems that must present information in such a way that it is explainable and understandable. For instance, concise representation, consistent representation, interpretability, understandability (Monge, 2000), arrangement, reasonable, readable (Naumann, et al., 1999), syntax, version control, semantics, aliases, origin (De Giacomo, et al., 2004), clarity, format, uniqueness, comparability (Celko \& McDonald, 1995), compatibility, meaning, presentation, and lack of 
confusion (Dasu \& Johnson, 2003) are considered as characteristics of representational IQ. Some of these dimensions of intrinsic (reliability), contextual (completeness, timeliness, and relevance), and representational (understandability) IQ can be applied to Facebook page's IQ as well.

Delone and McLean (2003) consider timeliness, accuracy, completeness, and relevance as dimensions of IQ for information system success. Some of DeLone and McLean (1992) and (Delone \& McLean, 2003)'s IQ dimensions also can be applied to determine Facebook page IQ. There is unanimity amongst researchers regarding the main attributes of IQ. It should be noted that the dimensions of IQ depends on the context of study. For Facebook users, it is important that the information is reliable and complete in such a way that the users are not required to refer to other websites to gather related information. In addition, the information posted in government Facebook page should be relevant, consistent, and understandable to assure that the users rely on the provided information. Therefore, considering Facebook as the context of this study, first hypothesis is developed:

H1: IQ dimensions of government Facebook page are a second order factor of reliability, completeness, relevancy, timeliness, and understandability.

\subsection{Expectation Confirmation Theory (ECT), Satisfaction, and Continuance Intention}

\subsubsection{ECT}

According to Oliver (1980), there are five stages in ECT model. First of all, users shape a preliminary expectation of a particular service or product in advance before purchasing the service or product. Secondly, users receive and use the service or product. After initial consumption, they shape their perceptions about its performance. Thirdly, they evaluate their primary expectations and perceived performance and they determine the degree to which their primary expectation is confirmed. Fourthly, users form a level of satisfaction based on their degree of confirmation and expectation level. Eventually, satisfied users decide to continue to use the product or service (repurchase/continuance intention).

R. W. Stone and Baker-Eveleth (2013) indicate that ECT model was developed based on the technology acceptance theory (Davis, 1989; Davis, Bagozzi, \& Warshaw, 1989) and the theory of planned behaviour (Ajzen \& Fishbein, 1980) together with the consumer behaviour literature. These theories ponder on users' motivation to embrace a new technology in lieu of CI of a technology. 
The ECT model and its different versions have been used in many researches pertaining to technology. S. C. Chen, Yen, and Hwang (2012) apply a different version of the ECT to investigate users' CI for Web 2.0 technologies (for instance, Twitter, Facebook, and blogs). They pinpointed four social elements (i.e., word-of-mouth, subjective norm, critical mass, and image) and satisfaction to have significant interrelationships effecting CI. In addition, Y. Lee and Kwon (2011) apply the ECT, and they change the model to be consisted of familiarity and intimacy to investigate CIs of web-based services. These two variables (familiarity and intimacy) were found to be important.

$\mathrm{Wu}$, Tsai, Chen, and $\mathrm{Wu}$ (2006) investigate CI of e-learning technologies by including self-efficacy factor into the ECT. The results of their study show important interrelationships among self-efficacy, perceived usefulness, confirmation, and satisfaction. Thong, Hong, and Tam (2006) extend the ECT by including ease of use and enjoyment to examine post-adoption behaviour in mobile commerce. In addition, in an e-learning environment, Chiu, Hsu, Sun, Lin, and Sun (2005) find that the elements of, usability, performance, value, and quality impact on satisfaction and eventually CI.

Roca, Chiu, and Martínez (2006) use the TAM theory relying on ECT. In their research, the performance factor is split into quality and usability. Liao, Chen, and Yen (2007) come up with a unified model based on the theories of ECT and theory of planned behaviour aimed to clarify users' CI of online services. They indicate that users' CI of eservice is contingent upon degree of satisfaction, and it is influenced by subjective norm and perceived usefulness.

\subsubsection{Information Quality, Satisfaction, and Continuance Intention}

To hypothesize the relationship between IQ and satisfaction, few studies are reviewed for justifying this relationship in Facebook context. Alhendawi and Baharudin (2013) find a positive relationship between IQ and satisfaction amongst Malaysian employees using webbased management information system. They adapt a questionnaire from previous researches to examine the employees of a non-profit international organization. Their study indicates that IQ has a positive impact on the effectiveness of online management information system as well. Koivumäki, Ristola, and Kesti (2008) conducted an empirical research on consumers' satisfaction toward mobile information services in Finland applying two field experiments. In their study, IQ is found to have a significant relationship with consumer satisfaction and CI. Muhammad, Yi, Naz, and Muhammad (2014) conducted a study on 
Chinese commitment to online retailing and they show that IQ positively influences esatisfaction and e-trust.

C.-C. Lin, Wu, and Chang (2011) surveyed Taiwan's university undergraduates, who had online purchase experience, to examine online customer satisfaction. Their results show that IQ positively affected online customer satisfaction. The results of Kassim, Jailani, Hairuddin, and Zamzuri (2012) study indicate a positive relationship between IQ and trust in IS system acceptance. They collected their data from students of higher learning institutes in Malaysia regarding their level of trust and satisfaction in using students IS. Jaiswal, Niraj, and Venugopal (2010) consider IQ as a context-specific determinant of online satisfaction of websites and they indicated that IQ is a significant predictor of online satisfaction and loyalty. They surveyed users of online retailing websites in India using mixed method (online and mail surveys). Using a sample of one middle-high school alumni and one university in Taiwan, C.-W. Chen (2010) find that IQ influences taxpayer satisfaction with online taxation system.

In addition, Chae, Kim, Kim, and Ryu (2002) consider IQ dimensions as contextual, content, connection, and interaction quality to examine the user satisfaction of Korean mobile Internet services. Surveying mobile Internet phone users through online surveys they find interaction and connection quality to be positively related to satisfaction. According to them, content and contextual quality does not have a positive relationship with satisfaction. Weerakkody, Irani, Lee, Hindi, and Osman (2014) conducted a meta-analysis of egovernment studies (147 articles) reviewing factors related to e-government user satisfaction mostly in business, management, and IS disciplines. They indicate that there are several limitations on studies conducted in e-government services such as self-selection bias, biased sample, small sample size, and absence of moderating variables. According to them, expectation-confirmation theory/model is only used in three studies (Brown \& Jayakody, 2008; Liao, et al., 2007; C. S. Lin, Wu, \& Tsai, 2005) and most researchers use TAM (29 studies), IS success model (10 studies), and diffusion of innovation (nine studies) and Weerakkody, et al. (2014) argue that researchers apply excessively random approaches/theories in e-government researches. Weerakkody, et al. (2014) indicate that merely 12 e-government studies used IQ as their independent variable from which six of them examined the relationship between IQ and satisfaction (four significant and two nonsignificant relationships) and four of them investigated the relationship between IQ and behavioural intention (three significant and one non-significant relationships). 
Bahry, Diana, Shahibi, Kamis, and Masrek (2014) propose a conceptual framework to study the relationship between IQ dimensions (intrinsic, contextual, representational, and accessibility IQ) and user satisfaction of government websites. Their research in progress will identify IQ variables that can be considered as web content measures for Malaysian government websites. This indicates that e-government studies still concentrate on government websites and it is shown that little research has been done in relevance to IQ and satisfaction and, to the best of our knowledge, no research has been conducted examining the relationship between IQ and user satisfaction of government Facebook page as well as IQ and CI of government Facebook page. Therefore, it is hypothesized that:

\section{H2: There is a positive relationship between IQ and satisfaction.}

H3: There is a positive relationship between IQ and CI of following Facebook page.

\subsubsection{Satisfaction and Continuance Intention of Government Facebook Page}

Satisfaction is referred to the "summary of psychological state resulting when the emotion surrounding disconfirmed expectations is combined with the consumer's previous feelings about the consumption experience" (Oliver, 1980). Satisfaction emphasizes an affective state pertaining to and stemming from a cognitive evaluation of the expectationperformance difference (confirmation) (Bhattacherjee, 2001; Chou, Min, Chang, \& Lin, 2010).

Satisfaction is a dynamic, complicated and context-specific concept (Giese \& Cote, 2000) that has been split into "transaction-specific" satisfaction and "cumulative satisfaction" (Bolton \& Drew, 1991; Cronin \& Taylor, 1994). Even if these two categories of satisfaction are mutually connected, they are dissimilar perception of satisfaction with unlike meaning or reasoning (Olsen \& Johnson, 2003). Transaction-specific satisfaction is a judgmental assessment of a particular service experienced at a unique point in time and cumulative satisfaction is the general assessment of whole services experienced over time (Johnson, Anderson, \& Fornell, 1995; Oliver, 2010).

Satisfaction is a substantial subject in service sector due to its anticipation of future behaviour or CI (Oliver, 1980). Several researches from different disciplines indicate the positive impact of satisfaction on CI (Bhattacherjee, 2001; Cronin, Brady, \& Hult, 2000;

Turel \& Serenko, 2006; Y. Wang \& Lo, 2002). This implies that satisfied service users are intended to repurchase/reuse the same service more than those who are dissatisfied. 
Apart from categorical classification of satisfaction i.e., transaction-specific and cumulative satisfaction, by the view of nature, it can be classified into cognitive satisfaction and emotional satisfaction (Bitner \& Hubbert, 1994). In this study, we adopt the cognitive satisfaction that refers to how citizens think about the service after their usage.

Roca, et al. (2006) find that satisfaction positively influences e-learning CI. They surveyed four international agencies of United Nations in different countries through webbased questionnaire to individuals who had taken at least one e-learning course. Koivumäki, et al. (2008) investigate consumers' satisfaction toward mobile information services in Finland using two field experiments. In their research, user satisfaction is found to have a significant relationship with $\mathrm{CI}$ in both hedonic and utilitarian use contexts. Chai, Herath, Park, and Rao (2006) find a positive relationship between e-government websites' user satisfaction and CI of e-government websites. They collected the data through a random digit-dial telephone survey from American adults in USA that was administered by a research centre. Administering an online survey from American citizens who had completed an online transaction via government portal, Orgeron and Goodman (2011) form an integrated model of e-government satisfaction and adoption based on TAM, SERVQUAL, and Web Trust Model to examine the citizen satisfaction of e-government services in USA. The results of their study show that usefulness or end-user convenience, assurance, Internet trust, and government trust are positively related to e-government satisfaction and adoption.

The results of study by D. Wang, Xu, and Chan (2015) indicate that perceived ease of use, perceived usefulness and arousal are positively associated with CI of social networking sites. Alalwan (2013) studies the impact of citizens' satisfaction on CI of Government 2.0 services in Bahrain using a web survey for e-government national website users. Their findings show that citizens' satisfaction positively influences CI to use Government 2.0 services. Government 2.0 is defined as the use of web 2.0 applications such as social networking, wikis, and blogs to engage citizens in a two-way online interaction (Thornton, 2010). In Alalwan (2013)'s study, there are only blogs and live chat tools for national portal of Bahrain. However, these results can be argued since social network application (such as Facebook page) is excluded and several studies precisely indicate social media as the building blocks of Government 2.0 (Bonsón, Torres, Royo, \& Flores, 2012; Millard, 2010). Alruwaie (2014) develops a conceptual framework for citizens' CI to use e-government systems based on ECT and social cognitive theory. He hypothesizes that there is a positive relationship between citizens' satisfaction and their CI to use e-government systems. This suggests that researches on e-government studies are still in its infancy level and further 
researches are required to empirically investigate the e-participation of citizens in using web 2.0 applications rather than ordinary websites or online e-government portals.

Using a sample of students from Chinese universities, Muhammad, et al. (2014) investigate the Chinese commitment to online retailing and they found a non-significant relationship between e-satisfaction and continuance commitment. In addition, according to Weerakkody, et al. (2014), in e-government studies, satisfaction is the fourth most frequently used independent variable (21 studies) and merely nine studies considered citizen satisfaction as their dependent variable. Further, only 10 studies examined the relationship between satisfaction and behavioural intention from which two studies found a negative relationship between these factors, according to Weerakkody, et al. (2014). Nevertheless, little is known on the relationship between these factors in government Facebook page. Accordingly,

\section{H4: Satisfied users will follow government Facebook page.}

H5: The direct relationship between IQ and CI of following Facebook page is mediated by satisfaction of government's Facebook page.

\subsubsection{Continuance Intention and Moderating Role of Different Facebook Pages}

The concept of CI is referred to an individual's will to keep using a service in the post-acceptance stage (Bhattacherjee, 2001) and many researchers have defined the concept in different ways such as "incorporation" (Kwon \& Zmud, 1987) and "confirmation" (Rogers, 2010). Intention to use has been modelled in various research areas of information sciences and consumer behaviour as the eventual dependent variable of interest (Jackson, Chow, \& Leitch, 1997; Yi \& La, 2004; Zeithaml, Berry, \& Parasuraman, 1996). These researchers consider CI to be an essential criterion of the prosperity of a new technology/service. P. J. H. Hu, Brown, Thong, Chan, and Tam (2009) develop an e-Tax service quality model within which service quality is a predictor of intentions to redo a behaviour. According to them, a citizen is more likely to use the e-Tax service if there is a better perception of perceived service quality.

Post-ECT, many researches have been conducted to examine users' CI in online service domains (Y. Lee \& Kwon, 2011). These researches are subdivided into expanding studies in terms of ECT (developing a new variable) and unified studies (combining the ECT and other theories). For instance, C. S. Lin, et al. (2005) expand the ECT model through including a path between playfulness and satisfaction. Atchariyachanvanich, Okada, and Sonehara (2007) extend Bhattacherjee (2001)'s model through including a new construct, 
customer loyalty, on CI. In addition, Vatanasombut, Igbaria, Stylianou, and Rodgers (2008) unify the commitment-trust theory, ECT, and TAM theory to come out with a model of CI. The results of their study indicate that commitment and trust are good predictors estimating CI.

I. Y. Chen (2007) considers the impacts of contextual and technological elements on CI in a longitudinal study. According to him, these elements positively impact on satisfaction and CI. Furthermore, several researches show customers' perceptions of a service or product in terms of high service quality, usefulness, and playfulness determine their CI stemming from heir satisfaction with service or product (Chiu, et al., 2005; C. S. Lin, et al., 2005; Liu, Leach, \& Bernhardt, 2005).

The constructs researched on CI studies can be divided into two groups: cognitive and affective. Cognitive factors refer to the mental process of knowing (Y. Lee \& Kwon, 2011), consisting facets like judgment, reasoning, and perception. Cognitive factors have been studied in CI of IT services, considering perceived value, confirmation, perceived usability, and disconfirmation (Y. Lee \& Kwon, 2011). In opposite, affective factors refer to specific states of feeling. Affective constructs of the CI are perceived enjoyment, playfulness, and pleasure. Since affective factors are temporary feelings, this study has a cognitive approach to CI, as the setting of government's Facebook page suggests a perpetual behaviour.

Shi, Lee, Cheung, and Chen (2010) find a positive relationship between satisfaction and CI of people using Facebook. They applied the expectation disconfirmation theory and used an online survey to collect data from individual Facebook users. Jin, Lee, and Cheung (2010) also find identical results in a study of an online bulletin board community. Further, Hofmann, Beverungen, Räckers, and Becker (2013) investigate how local governments use social networking sites for managing their communication with citizens in Germany applying a multi-method analysis (inductive and deductive content analysis) of official government Facebook pages' posts and comments. They find that multimedia features like videos and photos play a major role in the success of bilateral communication and Germany citizens prefer topics related to leisure activities. Bonsón, Royo, and Ratkai (2015) conducted a similar study investigating the impact of content and media types on citizens' engagement on Western European local governments' Facebook pages. They analysed the government Facebook pages posts' of 15 EU member countries belonging to four different public administrations and they find that content and media types (mainly links and photos) have a positive impact on citizens' engagement on Facebook. They indicate that European citizens do not show much interest toward marketing related contents as preferred by their local 
governments but they prefer municipal management contents pertaining to their daily lives. Referring aforementioned studies, a lack of theoretical research on CI of government Facebook pages is blatant.

In addition, Limayem and Cheung (2008) revise the ECT by incorporating IS habits as a moderator of $\mathrm{CI}$ and they investigated online-based learning technologies. Their findings reveal that satisfaction and prior behaviour influence on IS continuance and IS habit moderates the relationships in the ECT. According to Caers, et al. (2013), previous research has paid attention to differences in Facebook behaviour merely relating to race, age, social status, personality, and gender. Weerakkody, et al. (2014) consider no moderating variable in e-government studies as a methodological limitation. The results of study by Chai, et al. (2006) show gender and race difference as moderating factors on the relationship between users' satisfaction and e-government websites CI. Orgeron and Goodman (2011) find that egovernment satisfaction and CI are unaffected by demographic variables (age, gender, education, income, and race) and their moderation effect is non-significant. Since no studies, to the best of our knowledge, are conducted referring the moderating effect of Facebook pages in e-government discipline, it is proposed that different government Facebook pages have a moderation effect on degree of citizen satisfaction and CI. Therefore, it is hypothesized that:

H6: Different government Facebook pages moderate the relationship between IQ and satisfaction of government Facebook page as well as between IQ and CI of government Facebook page.

Figure 1 shows the theoretical model of this study. The links between the constructs were broadly discussed in previous sections. This theoretical framework is mainly based on theory of ECT (Oliver, 1980), and IS success model (DeLone \& McLean, 1992).

Figure 1. Theoretical Model (Insert Here)

\section{Research method}

\subsection{Pre-test and Pilot test}

The designed questionnaire of this study was pre-tested with seven $\mathrm{PhD}$ research students to check the questionnaire design. According to Burns and Bush (2003), a pre-test of 
5 to 10 respondents is appropriate to find the design issues related to a survey questionnaire. In a focus group session, the respondents were asked to answer the questions and they were able to finish the survey within 15 minutes. Based on the comments and feedbacks received for each question, the wordings and language of some questions were modified. In addition, the order of some questions was changed for providing a logical sequence. The revised version of the survey questionnaire was used for pilot test accordingly. A total of 60 paperand-pencil questionnaires were issued to pre-test the measurement items and to come out with the final refinements of the final version of the questionnaire. The authors hired an assistant for the purpose of pilot study. All questionnaires were retrieved and Cronbach's alpha and composite reliability of constructs were higher than 0.8 and 0.9 respectively.

To conduct the main data collection, a questionnaire was developed in two main sections to capture the information related to respondents' background and to collect information about the proposed theoretical model (Figure 1). The measurement items of IQ were adopted from Y. W. Lee, et al. (2002), and items of satisfaction and CI of following government Facebook page were adopted from Bhattacherjee (2001).

\subsection{Data screening and assessment of sample size adequacy}

The questionnaires were distributed among university students in Malaysia. 450 paper-and-pencil questionnaires were distributed among respondents from which 380 were received. Checking case screening for missing data in rows through Microsoft Excel software and importing the data from SPSS Statistics version 21, a new column was added in Excel using the "COUNTBLANK" function to observe how many missing values each case has. After deleting 14 cases with more than $95 \%$ missing value (these respondents only filled up the demographics), the biggest value of count-blank function was 3 , which is not critical. If $10 \%$ or $15 \%$ (Hair, Hult, Ringle, \& Sarstedt, 2013, p. 51) of each case has missing value then it should be deleted. Therefore, the data can be imputed. To handle unengaged responses, the standard deviation of each case was calculated using Microsoft Excel software. Four respondents answered all the questions with the value of 7 (strongly agree). Therefore, these cases are deleted. Rests of cases have had a standard deviation more than 0.462 . Finally, 362 valid questionnaires (80.44\% response rate) were accepted for data analysis. Table 1 depicts respondents' characteristics.

Table 1: Sample characteristic $(N=362)$ (Insert here) 
To treat the missing data in columns, expectation maximization algorithm is used through SPSS software. This algorithm estimates that the data is missing randomly and not in a systematic way. To show that the data is missing randomly, the Little's MCAR test (Little, 1988) was performed and the results showed that our data is missing randomly (Chi-Square $=$ 483.164, DF $=445$, Sig. $=.182$ ). Finally, the percentage of missing values for measurement items is below $1 \%$, which is satisfactory. Therefore, the expectation maximization algorithm is applied for these missing values accordingly.

The sample size criterion should be determined through power analysis for SEM (Hair, et al., 2013; Valaei \& Jiroudi, 2016). This study uses a-priori sample size calculator for SEM (Soper, 2015). Inputting the required information such as $95 \%$ desired statistical power level, 7 constructs of this study, 25 indicators, 0.05 probability level, as well as anticipated high effect size of 0.5 , medium effect size of 0.3 , and small effect size of 0.1 , the required number of sample size for these effect sizes are 133, 133, and 233 respectively. Since the sample size of this study is 362 , this requirement is met as well.

\subsection{Outliers and normality}

Potential outliers were spotted in the dataset. There is a controversy amongst researchers regarding deleting or keeping the outliers. To examine whether the outliers affect the further analyses, the difference between the mean value and 5\% trim mean are considered. If there is a huge difference between these values, then the researcher should consider deleting the outliers. In our dataset, the difference between the mean value and $5 \%$ trim mean is trivial; therefore, the outliers are kept, as they do not have any effect on the dataset.

To test the normality of the data set, the values of Skewness and Kurtosis are helpful. The rule of thumb for Skewness and Kurtosis is values between -1.5 and 1.5 (Tabachnick \& Fidell, 2013). Results shows that all items score between -1 and 1. Therefore, none of measurement items has issues of Skewness/Kurtosis and the normality of distribution is met.

\subsection{Common method variance (CMV)}

After collecting primary data, there is a necessity to test the common method bias to make sure that no systematic bias is influencing the collected data (Podsakoff, MacKenzie, Lee, \& Podsakoff, 2003; Valaei, 2017). In this study Harman's one-factor test (Harman, 1976) is used to test the common method bias (Podsakoff \& Organ, 1986). In this approach, 
all principal constructs are entered into one principal component factor analysis. The results of Harman's one-factor test (Harman, 1976) showed that principal component of one fixed factor explains less than $50 \%$ of the variance (47.2\%). In addition, following Bagozzi's method, the highest correlation between constructs is 0.771 (see Table 4a), which should be below 0.9 (Bagozzi, Yi, \& Phillips, 1991). Therefore, these are no common method bias in the collected data. Therefore, there is no CMV in the collected data.

\subsection{Non-response bias}

To address non-responsive bias, wave analysis was applied to test whether there is any difference between early and late respondents (Menachemi, 2011). To do the wave analysis, early respondents and late respondents were separated into different datasets. Early (233 cases) and late respondents (129 cases) were divided and T-test was applied to examine the differences between the means. It was found that there was no significant difference between these two groups; therefore, this study does not have non-response bias.

\subsection{A Complementary partial least square (PLS) path modeling approach}

PLS-SEM enables the researchers to assess both causal relationships among indicators/items as well as the further causal relationships of latent constructs (Gudergan, Ringle, Wende, \& Will, 2008). The variance of the endogenous latent constructs are being maximized by PLS-SEM (Hair, Sarstedt, Ringle, \& Mena, 2012). As a variance-based SEM, PLS statistical approaches is based on component construct concept that is suitable to explain the existing complex relationships (Sarstedt, 2008; Valaei, Rezaei, \& Ismail, 2017). "The PLS algorithm allows each indicator to vary in how much it contributes to the composite score of the latent variable" (Chin, Marcolin, \& Newsted, 2003, p. 25). Through new advancements in PLS techniques, the approach has all abilities of SEM and PLS is called as a fully-fledged SEM approach (Henseler, Hubona, \& Ray, 2016) and PLS models can be assessed through tests of model fit, approximate measures of model fit based on bootstrapping (Dijkstra \& Henseler, 2015), heterotrait-monotrait ratio of correlations (HTMT) (Henseler, Ringle, \& Sarstedt, 2015) as a new measure of discriminant validity, and Dijkstra-Henseler's rho $(\rho A)$ as the most important reliability measure of PLS (Dijkstra \& Henseler, 2015).

This study introduces a complementary PLS application within which at the first stage, ADANCO 1.1 software (Henseler \& Dijkstra, 2015) is applied to test the goodness of model fit and at the second stage, SmartPLS 3 software (Ringle, Wende, \& Becker, 2014) is 
applied to assess both measurement model and structural model. Therefore, this study suggests that researchers should apply such combinative PLS approach to make it a formidable statistical tool.

\section{Results}

\subsection{Goodness of model fit}

The goodness of fit assessment should be done at the beginning of model assessment before examining the measurement and structural model (Henseler, et al., 2016). Therefore, researchers need to report the model fit by means of inference statistics (tests of model fit) or use of fit indices (assessment of approximate model fit) (Dijkstra \& Henseler, 2015; Henseler, et al., 2016). To assess the goodness of model fit, ADANCO software provides standardized root mean square residual (SRMR) as the only appropriate measure of model fit (L.-t. Hu \& Bentler, 1998), as well as other model fit criteria relying on the bootstrap to identify the likelihood of obtaining a discrepancy between the empirical and model-implied correlation matrix (Dijkstra \& Henseler, 2015; Henseler, et al., 2016) such as geodesic discrepancy $\left(\mathrm{d}_{\mathrm{G}}\right)$, and unweighted least squares discrepancy $\left(\mathrm{d}_{\mathrm{ULS}}\right)$ (Dijkstra \& Henseler, 2015). According to Hair, et al. (2014), a value of less than 0.1 (Hair, et al., 2014) or 0.08, a more conservative view (L.-t. Hu \& Bentler, 1998), is a good fit for SRMR. Table 2 shows the tests of model fit as well as SRMR fit index. According to Henseler, et al. (2016), the criteria of overall model are: SRMR $<95 \%$ of bootstrap quantile (HI95 of SRMR), $\mathrm{d}_{\text {ULS }}<$ 95\% of bootstrap quantile (HI95 of $d_{U L S}$ ), and $d_{G}<95 \%$ of bootstrap quantile (HI95 of $d_{G}$ ). Shown in Table 2, these criteria are met; therefore, the model has a good fit.

Table 2: Goodness of model fit (Insert here)

\subsection{Construct validity and reliability}

As shown in Table 2, all the reflective constructs loadings are more than the minimum threshold value of 0.7 . As it is shown by the composite reliability (CR) values, Table 3 indicates that all the latent constructs have high level of internal consistency reliability, the CR ought to be higher than 0.70 (Hair, Ringle, \& Sarstedt, 2011) and the Cronbach's alpha values are between 0.886 and 0.949 . The values of $\rho_{\mathrm{A}}$ are also acceptable (more than 0.7) (Henseler, et al., 2016). Examining the convergent validity, the Average Variance Extracted 
(AVE) values are above the minimum required level of 0.50 , showing convergent validity for all latent constructs.

Table 3: Construct validity (Insert here)

There are three steps in examining discriminant validity shown in Tables $4 \mathrm{a}, 4 \mathrm{~b}$, and 4c. According to Table 4a, the Fornell and Larcker criterion (Fornell \& Larcker, 1981) indicates that the correlations that exist among the latent constructs are outlined as offdiagonal values. Furthermore, the diagonal values are depicted as square values of AVEs. A comparison of the loadings across the columns in Table $4 \mathrm{~b}$ exhibits that an indicator's loadings on its own construct is higher in all cases compared to all of its cross-loadings with other constructs. Table $4 \mathrm{c}$ shows the discriminant validity HTMT ratio of correlation. The HTMT values are below the threshold of 0.90 (Gold \& Arvind Malhotra, 2001; Teo, Srivastava, \& Jiang, 2008).

Table 4a: Discriminant validity - Fornell-Larcker criterion (Insert here)

Table 4b: Discriminant validity- Cross loadings (Insert here)

Table 4c: Discriminant validity - Heterotrait-Monotrait ratio (Insert here)

Furthermore, for assessing the higher order constructs in PLS technique (B. Wilson \& Henseler, 2007) also known as hierarchical component model (Chin, et al., 2003), Table 5 depicts the weights of first-order constructs on IQ using the repeated indicators approach (Lohmoller, 1988). Statistical assessment in Table 5 supports that IQ of government Facebook page is a second order reflective construct designed by five first-order latent constructs including reliability, completeness, relevancy, timeliness, and understandability, supporting $\mathrm{H} 1$.

Table 5: Weights of first-orders on information quality second-order construct (Examining H1) (Insert here)

\subsection{Structural model}

The hypotheses are tested through the results of bootstrapping with 5000 resampling. Table 6 shows that all the direct hypotheses are supported with high path coefficients and Tvalues. Therefore, IQ of government Facebook page is a significant factor in satisfaction and 
CI of following Facebook pages. In addition, applying the guidelines of Hair, et al. (2013) in mediation analysis, the Variance Accounted For (VAF) of 50\% in Table 7 indicates that the direct relationship between IQ and CI of following Facebook page is partially mediated by satisfaction of government's Facebook page.

Table 6: Hypothesis testing (Direct effects) (Insert here)

Table 7: Mediation analysis (Insert here)

The $\mathrm{R}^{2}$ value of CI of following Facebook page (shown in Figure 2) suggests that $63.3 \%$ of changes in this component can be predicted through IQ and satisfaction of government's Facebook page. The $\mathrm{R}^{2}$ value of satisfaction of government's Facebook page suggests that $62 \%$ of changes in this component can be predicted through IQ. Another assessment of predictive accuracy of a model is its predictive relevance of $\mathrm{Q}^{2}$ values (Geisser, 1974; M. Stone, 1974). $\mathrm{Q}^{2}$ values of 0.527 and 0.528 for satisfaction and CI of following government's Facebook page indicate high predictive relevancy of these latent constructs.

Figure 2: PLS results (Insert here)

\subsubsection{Partial least square-multi group analysis (PLS-MGA)}

To address the last hypothesis (H6), Facebook page is considered as a categorical moderator variable. It should be noted that only 9 Malaysian government Facebook pages are examined in this study. PLS-MGA is applied via using the percentile bootstrapping method to find out the differences among different government Facebook pages. The subgroup of "others" is discarded from PLS-MGA due to its singular matrix error. This error happens when there is a huge gap between the number of cases under each group (Sarstedt, Henseler, \& Ringle, 2011). Table 8a, 8b, and 8c show the differences in the path coefficients and Pvalues of comparisons across Facebook pages.

In PLS-MGA, based on the guidelines that are outlined by (Henseler, Ringle, \& Sinkovics, 2009), the percentages smaller than 0.05 and higher than 0.95 indicate a significant difference of a specific PLS path coefficient among groups. Therefore, the result is significant at $5 \%$ error level if the $\mathrm{P}$-value is smaller than 0.05 or is higher than 0.95 . According to Henseler, et al. (2009), the percentile below 0.05 points out that the bootstrapping results of group 1 is higher than group 2. In addition, percentiles higher than 0.95 indicate that the bootstrapping results of group 2 are higher than group 1. According to 
Table 8a, comparing Jobs Malaysia Facebook page and KWSP Facebook page, the results indicate that the path coefficient of IQ $\rightarrow \mathrm{CI}$ of following government Facebook page is stronger for KWSP Facebook page.

Furthermore, shown in Table 8b, comparing JPJ Facebook page and KPM Facebook page, the findings indicate that the path coefficient of IQ $\rightarrow$ Satisfaction of government Facebook page is stronger for JPJ Facebook page. The results of Table 8c can also be analysed similarly. Therefore, different government Facebook pages moderate the relationship between IQ and satisfaction of government Facebook page as well as between IQ and CI of government Facebook page.

Table 8a: Structural relationship and hypothesis testing across different Facebook Pages (Examining H6 through PLS-MGA) (Insert here)

Table 8b: Structural relationship and hypothesis testing across different Facebook Pages (Examining H6 through PLS-MGA) (Insert here)

Table 8c: Structural relationship and hypothesis testing across different Facebook Pages (Examining H6 through PLS-MGA) (Insert here)

Finally, since Malaysia is a multicultural country, it is noteworthy to examine the extent to which the structural relationships differ across ethnic groups. Comparing the differences between Malay, Chinese, and Indian groups, the results of PLS-MGA reveal that the path coefficient of IQ $\rightarrow$ CI of following government Facebook page is stronger for Chinese ethnicity. The path coefficient of IQ $\rightarrow$ Satisfaction of government Facebook page is also stronger for Indian ethnic group.

\section{Discussion and contribution}

During the past decade, the size and growth rate of Facebook has evoked the attention of researchers from divergent fields of inquiry (Caers, et al., 2013). Since Facebook succeeds in achieving universal diffusion, researchers need to study differences in its usage and performance (Gulati \& Williams, 2013). The stream of research on political communication is moving toward how technology mediated communication bolsters citizen-government interaction (Soon \& Soh, 2014). Social media provides citizens to show their ideas without being controlled by the corrupting influence of politics and money (Haro-de-Rosario, et al., In Press). Examining how citizens use social media and understanding factors associated with 
IQ of government Facebook pages help governments in managing content generation on Facebook and other social media.

This study introduced the new concept of CI of government Facebook page based on theories of ECT and IS success. It is shown that unlike service and product, the service quality of government Facebook page is resorted to the IQ of the page, as the users are information savvy. There is a lack of research focusing on IQ in e-government domain (Alruwaie, 2014) and this study has attempted to show the value of IQ dimensions, namely reliability, completeness, timeliness, relevance, and understandability in satisfaction of government Facebook page and CI of following government Facebook page. It was found that IQ is a second-order construct of five first-order latent constructs. Even though Weerakkody, et al. (2014) mention the discrepancy on the positive/negative relationship between IQ and satisfaction, the results highlighted the positive association between IQ and satisfaction of government's Facebook page, which is in line with Muhammad, et al. (2014) and C.-C. Lin, et al. (2011).

Indicating the negative impact of satisfaction on behavioural intention (Weerakkody, et al., 2014), the findings also imply the positive role of IQ on CI of following government Facebook page, which is in line with previous researches such as Alalwan (2013) and Alruwaie (2014). In addition, satisfaction of government's Facebook page was found as a partial mediator to the relationship between IQ and CI of following government Facebook page and applying PLS-MGA, different Facebook pages showed a moderation effect on direct relationships of the theoretical model. In line with Papadomichelaki and Mentzas (2012)'s study on e-government websites, this study also believes that citizens are information seekers in the social media domain.

There are three main contributions: theoretical, practical, and methodological. This study has a rigorous review on the literature concerning IQ, satisfaction, Facebook in egovernment, CI, and social media based on theories of ECT and IS success. Current research was accomplished leveraging existing validated measures from previous literature and applying these measures to the government Facebook realm. Since Malaysia is multi-cultural and it shares similar culture with neighbouring countries, the findings can also be useful for other Southeast Asian countries. The findings of PLS-MGA showed discrepancy across ethnic groups. Comparing the differences between Malay, Chinese, and Indian groups, the stronger path coefficient of IQ $\rightarrow$ CI of following government Facebook page for Chinese ethnicity implies that Chinese are more concerned with IQ of Malaysian government Facebook page and their CI to follow the page is contingent upon high IQ in terms of 
reliability, completeness, timeliness, relevance, and understandability. In addition, the stronger path coefficient of IQ $\rightarrow$ Satisfaction of government Facebook page for Indian ethnic group suggests that, compared with other ethnic groups, Indians are more satisfied with the government Facebook pages.

The role of Facebook in political mobilization, uprisings, and revolutions is blatant (R. E. Wilson, Gosling, \& Graham, 2012). In the arena, where Facebook sparks revolutions (Rieder, Abdulla, Poell, Woltering, \& Zack, 2015), for e.g. Egyptian revolution (Alaimo, 2015), appreciating its implications on public sphere is imperative. Facebook's option to "like" or respond to a comment/post creates debate and generates a sense of community and collective identity (Harlow, 2012). Facebook allows organizations to convey messages swiftly and communicate with its stakeholders immediately (Ye \& Ki, 2017). This helps organizations or governments to notice misperceptions, manage crisis communication messages, and diminish the negative effects of online Facebook users on the public sphere. However, it attracts the users to further contribute to online participation.

Facebook is also considered as the building blocks of Government 2.0 (Bonsón, et al., 2012; Millard, 2010) and CI of Facebook usage is a challenge in IS discipline (Al-Debei, et al., 2013). A government Facebook page is consisted of chatting citizens who not only communicate to seek information but also providing it to each other (Tampere, et al., 2016). Thus, local governments need to come out with Facebook strategies to address the needs of faith holders, hate holders, negatively engaged citizens (Bowden, et al., 2016), and supporters (Coombs \& Holladay, 2014) through providing quality information that is reliable, complete, relevant, and understandable in a timely manner. E-government managers can recognize the significance of the IQ dimensions and match them with their e-government models. Understanding IQ dimensions and its role in CI of following government Facebook page can help e-government managers and mainly the administrators of their Facebook profiles to encourage citizens' involvement in e-government use and it helps managers to deal with the changes social media delivers.

To address Rodríguez Bolívar, Alcaide Muñoz, and López Hernández (2016)’s statement on immature research methods in e-government studies, as a methodological contribution, the study introduced a synergistic PLS application, a fully-fledged SEM approach, as a new methodology in VB-SEM through using ADANCO advanced composite modelling and SmartPLS software. At first stage, the results of ADANCO were used to test the goodness of model fit. And at the second stage, SmartPLS was used to assess both measurement and structural models. 
Policy makers can reduce the gap between citizens and government through providing an interactive environment. Social media has facilitated this process through providing a myriad of technologies such as Facebook and Twitter. A prosperous e-government policy is the one that involves its citizens in policymaking and provides timely information. This study showed that for Facebook users, it is important that the information is reliable and complete in such a way that the users are not required to refer to other websites to gather related information. In addition, the information posted in government Facebook page need to be relevant, consistent, and understandable to assure that the users rely on the provided information.

This study categorized IQ dimensions under five generic characteristics. Other IQ dimensions might be involved in social media context in general and Facebook in particular. This signals for further investigation on other IQ dimensions. In addition, this research is based on G2C context in which ECT and IS success theories were employed to shed light on CI of following government Facebook page. Further examination is required to identify users/citizens' perception of social media in e-government applying other psychological theories such as social learning theory and social cognitive theory. Finally, the concept of social media involves interaction and future studies should examine the $\mathrm{C} 2 \mathrm{G}$ context and provide knowledge referring under what circumstances citizens can influence or encourage egovernment practices and policies.

\section{References}

Ajzen, I., \& Fishbein, M. (1980). Understanding attitudes and predicting social behaviour. Englewood Cliffs, NJ: Prentice-Hall.

Al-Debei, M.M., Al-Lozi, E., \& Papazafeiropoulou, A. (2013). Why people keep coming back to Facebook: Explaining and predicting continuance participation from an extended theory of planned behaviour perspective. Decision Support Systems, 55(1), 43-54.

Alaimo, K. (2015). How the Facebook Arabic Page "We Are All Khaled Said" Helped Promote the Egyptian Revolution. Social Media + Society, 1(2), 2056305115604854.

Alalwan, J.A. (2013). Continuance Intention to Use Government 2.0 Services: The Impact of Citizens' Satisfaction and Involvement. International Journal of Electronic Government Research (IJEGR), 9(3), 58-73.

Alhendawi, K.M., \& Baharudin, A.S. (2013). The Mediating Role of Web User Satisfaction on Information Quality, Service Quality and the Effectiveness of Web-based Information System. Journal of Convergence Information Technology, 8(12), 29-40.

Alruwaie, M. (2014). The Role of Social Influence and Prior Experience on Citizens' Intention to Continuing to Use E-Government Systems: A Conceptual Framework. International Journal of Electronic Government Research (IJEGR), 10(4), 1-20. 
Atchariyachanvanich, K., Okada, H., \& Sonehara, N. (2007). What keeps online customers repurchasing through the internet? ACM SIGecom Exchanges, 6(2), 47-57.

Bagozzi, R.P., Yi, Y., \& Phillips, L.W. (1991). Assessing construct validity in organizational research. Administrative science quarterly, 36(3), 421-458.

Bahry, S., Diana, F., Shahibi, M.S., Kamis, Y., \& Masrek, M.N. (2014). Preffered information quality factors as a web content quality measures on malaysian government websites: A conceptual paper. In Technology Management and Emerging Technologies (ISTMET), 2014 International Symposium on (pp. 400-405): IEEE.

Batini, C., Catarci, T., \& Scannapiceco, M. (2004). A survey of data quality issues in cooperative information systems. In 23rd international conference on conceptual modeling (ER). Shanghai, China.

Bettoni, M.C., Andenmatten, S., \& Mathieu, R. (2007). Knowledge cooperation in online communities: A duality of participation and cultivation. Electronic Journal of Knowledge Management, 5(1), 1-6.

Bhattacherjee, A. (2001). Understanding information systems continuance: an expectationconfirmation model. MIS quarterly, 25(3), 351-370.

Bilenko, M., \& Mooney, R.J. (2003). Adaptive duplicate detection using learnable string similarity measures. In Proceedings of the ninth ACM SIGKDD international conference on Knowledge discovery and data mining (pp. 39-48): ACM.

Bitner, M.J., \& Hubbert, A.R. (1994). Encounter satisfaction versus overall satisfaction versus quality. In T.R. Roland \& L.O. Richard (Eds.), Service quality: New directions in theory and practice (pp. 72-84). New York: Sage Publications.

Bolton, R.N., \& Drew, J.H. (1991). A multistage model of customers' assessments of service quality and value. Journal of Consumer Research, 17(4), 375-384.

Bonsón, E., Royo, S., \& Ratkai, M. (2015). Citizens' engagement on local governments' Facebook sites. An empirical analysis: The impact of different media and content types in Western Europe. Government Information Quarterly, 32(1), 52-62.

Bonsón, E., Torres, L., Royo, S., \& Flores, F. (2012). Local e-government 2.0: Social media and corporate transparency in municipalities. Government Information Quarterly, 29(2), 123-132.

Bowden, J.L.-H., Luoma-Aho, V., Naumann, K., Brodie, R., Hollebeek, L., \& Conduit, J. (2016). Developing a spectrum of positive to negative citizen engagement. In R.J. Brodie, L. Hollebeek \& J. Conduit (Eds.), Customer Engagement: Contemporary Issues and Challenges (pp. 257-277). New York, NY: Routledge.

Brown, I., \& Jayakody, R. (2008). B2C e-commerce success: A test and validation of a revised conceptual model. The Electronic Journal Information Systems Evaluation, 11(3), 167-184.

Burns, A.C., \& Bush, R.F. (2003). Marketing research: Online research applications: Prentice Hall.

Caers, R., De Feyter, T., De Couck, M., Stough, T., Vigna, C., \& Du Bois, C. (2013). Facebook: A literature review. New Media \& Society, 15(6), 982-1002.

Celko, J., \& McDonald, J. (1995). Don't warehouse dirty data. Datamation-Highlands Ranch, 41(19), 42-55.

Chae, M., Kim, J., Kim, H., \& Ryu, H. (2002). Information quality for mobile internet services: A theoretical model with empirical validation. Electronic Markets, 12(1), $38-46$.

Chai, S., Herath, T., Park, I., \& Rao, H. (2006). Repeated Use of E-Gov Web Sites: A Satisfaction and Confidentiality Perspective. International Journal of Electronic Government Research (IJEGR), 2(3), 1-22. 
Chen, C.-W. (2010). Impact of quality antecedents on taxpayer satisfaction with online taxfiling systems-An empirical study. Information \& management, 47(5), 308-315.

Chen, I.Y. (2007). The factors influencing members' continuance intentions in professional virtual communities-a longitudinal study. Journal of Information Science, 33(4), 451467.

Chen, S.C., Yen, D.C., \& Hwang, M.I. (2012). Factors influencing the continuance intention to the usage of Web 2.0: An empirical study. Computers in Human Behavior, 28(3), 933-941.

Chin, W.W., Marcolin, B.L., \& Newsted, P.R. (2003). A partial least squares latent variable modeling approach for measuring interaction effects: Results from a Monte Carlo simulation study and an electronic-mail emotion/adoption study. Information systems research, 14(2), 189-217.

Chiu, C.-M., Hsu, M.-H., Sun, S.-Y., Lin, T.-C., \& Sun, P.-C. (2005). Usability, quality, value and e-learning continuance decisions. Computers \& Education, 45(4), 399-416.

Chou, S.-W., Min, H.-T., Chang, Y.-C., \& Lin, C.-T. (2010). Understanding continuance intention of knowledge creation using extended expectation-confirmation theory: an empirical study of Taiwan and China online communities. Behaviour \& Information Technology, 29(6), 557-570.

Coombs, W.T., \& Holladay, S.J. (2014). How publics react to crisis communication efforts: Comparing crisis response reactions across sub-arenas. Journal of Communication Management, 18(1), 40-57.

Cronin, J.J., Brady, M.K., \& Hult, G.T.M. (2000). Assessing the effects of quality, value, and customer satisfaction on consumer behavioral intentions in service environments. Journal of Retailing, 76(2), 193-218.

Cronin, J.J., \& Taylor, S.A. (1994). SERVPERF versus SERVQUAL: reconciling performance-based and perceptions-minus-expectations measurement of service quality. the Journal of Marketing, 58(1), 125-131.

Cumbie, B.A., \& Kar, B. (2014). A Study of Local Government Website Inclusiveness: The Gap Between E-government Concept and Practice. Information Technology for Development, 22(1), 1-20.

Dasu, T., \& Johnson, T. (2003). Exploratory data mining and data cleaning (Vol. 479): John Wiley \& Sons.

Davis, F.D. (1989). Perceived usefulness, perceived ease of use, and user acceptance of information technology. MIS quarterly, 13(3), 319-340.

Davis, F.D., Bagozzi, R.P., \& Warshaw, P.R. (1989). User acceptance of computer technology: a comparison of two theoretical models. Management science, 35(8), 982-1003.

De Giacomo, G., Lembo, D., Lenzerini, M., \& Rosati, R. (2004). Tackling inconsistencies in data integration through source preferences. In Proceedings of the 2004 international workshop on Information quality in information systems (pp. 27-34): ACM.

DeLone, W.H., \& McLean, E.R. (1992). Information systems success: The quest for the dependent variable. Information systems research, 3(1), 60-95.

Delone, W.H., \& McLean, E.R. (2003). The DeLone and McLean model of information systems success: a ten-year update. Journal of Management Information Systems, 19(4), 9-30.

Dijkstra, T.K., \& Henseler, J. (2015). Consistent and asymptotically normal PLS estimators for linear structural equations. Computational statistics \& data analysis, 81, 10-23.

Fornell, C., \& Larcker, D.F. (1981). Evaluating Structural Equation Models With Unobservable Variables and Measurement Error. Journal of marketing research, 18(1), 39-50. 
Geisser, S. (1974). A predictive approach to the random effect model. Biometrika, 61(1), 101-107.

Giese, J.L., \& Cote, J.A. (2000). Defining consumer satisfaction. Academy of marketing science review, 1(1), 1-22.

Gold, A.H., \& Arvind Malhotra, A.H.S. (2001). Knowledge management: An organizational capabilities perspective. Journal of Management Information Systems, 18(1), 185214.

Grömping, M. (2014). 'Echo Chambers' Partisan Facebook Groups during the 2014 Thai Election. Asia Pacific Media Educator, 24(1), 39-59.

Gudergan, S.P., Ringle, C.M., Wende, S., \& Will, A. (2008). Confirmatory Tetrad Analysis in PLS Path Modeling. Journal of business research, 61(12), 1238-1249.

Gulati, G.J., \& Williams, C.B. (2013). Social Media and Campaign 2012. Social Science Computer Review, 31(5), 577-588.

Hair, J.F., Henseler, J., Dijkstra, T., Sarstedt, M., Ringle, C., Diamantopoulos, A., Straub, D., Ketchen, D., GTM, H., \& Calantone, R. (2014). Common Beliefs and Reality about Partial Least Squares: Comments on Rönkkö and Evermann. Organizational Research Methods, 17(2), 182-209.

Hair, J.F., Hult, G.T.M., Ringle, C., \& Sarstedt, M. (2013). A primer on partial least squares structural equation modeling (PLS-SEM): Sage Publications.

Hair, J.F., Ringle, C.M., \& Sarstedt, M. (2011). PLS-SEM: Indeed a Silver Bullet. Journal of Marketing Theory and Practice, 18(2), 139-152.

Hair, J.F., Sarstedt, M., Ringle, C.M., \& Mena, J.A. (2012). An Assessment of the Use of Partial Least Squares Structural Equation Modeling in Marketing Research. Journal of the academy of marketing science, 40(3), 414-443.

Harlow, S. (2012). Social media and social movements: Facebook and an online Guatemalan justice movement that moved offline. New Media \& Society, 14(2), 225-243.

Harman, H.H. (1976). Modern factor analysis. Chicago, USA: The University of Chicago Press.

Haro-de-Rosario, A., Sáez-Martín, A., \& Caba-Pérez, M.d.C. (In Press). Using social media to enhance citizen engagement with local government: Twitter or Facebook? New Media \& Society, 0(0), 1-21.

Henseler, J., \& Dijkstra, T. (2015). ADANCO 1.1. Kleve, Germany: Composite Modeling.

Henseler, J., Hubona, G., \& Ray, P.A. (2016). Using PLS path modeling in new technology research: updated guidelines. Industrial Management \& Data Systems, 116(1), 2-20.

Henseler, J., Ringle, C.M., \& Sarstedt, M. (2015). A new criterion for assessing discriminant validity in variance-based structural equation modeling. Journal of the Academy of Marketing Science, 43(1), 115-135.

Henseler, J., Ringle, C.M., \& Sinkovics, R.R. (2009). The use of partial least squares path modeling in international marketing. In New Challenges to International Marketing (pp. 277-319).

Hofmann, S., Beverungen, D., Räckers, M., \& Becker, J. (2013). What makes local governments' online communications successful? Insights from a multi-method analysis of Facebook. Government Information Quarterly, 30(4), 387-396.

Hu, L.-t., \& Bentler, P.M. (1998). Fit indices in covariance structure modeling: Sensitivity to underparameterized model misspecification. Psychological methods, 3(4), 424-453.

Hu, P.J.H., Brown, S.A., Thong, J.Y., Chan, F.K., \& Tam, K.Y. (2009). Determinants of service quality and continuance intention of online services: The case of eTax. Journal of the American Society for Information Science and Technology, 60(2), 292306. 
Jackson, C.M., Chow, S., \& Leitch, R.A. (1997). Toward an understanding of the behavioral intention to use an information system. Decision Sciences, 28(2), 357-389.

Jaiswal, A.K., Niraj, R., \& Venugopal, P. (2010). Context-general and context-specific determinants of online satisfaction and loyalty for commerce and content sites. Journal of Interactive Marketing, 24(3), 222-238.

Jin, X.-L., Lee, M.K., \& Cheung, C.M. (2010). Predicting continuance in online communities: model development and empirical test. Behaviour \& Information Technology, 29(4), 383-394.

Johnson, M.D., Anderson, E.W., \& Fornell, C. (1995). Rational and adaptive performance expectations in a customer satisfaction framework. Journal of Consumer Research, 21(4), 695-707.

Kassim, E.S., Jailani, S.F.A.K., Hairuddin, H., \& Zamzuri, N.H. (2012). Information system acceptance and user satisfaction: The mediating role of trust. Procedia-Social and Behavioral Sciences, 57, 412-418.

Koivumäki, T., Ristola, A., \& Kesti, M. (2008). The effects of information quality of mobile information services on user satisfaction and service acceptance-empirical evidence from Finland. Behaviour \& Information Technology, 27(5), 375-385.

Kwon, T.H., \& Zmud, R.W. (1987). Unifying the fragmented models of information systems implementation. In Critical issues in information systems research (pp. 227-251): John Wiley \& Sons, Inc.

Lee, Y., \& Kwon, O. (2011). Intimacy, familiarity and continuance intention: An extended expectation-confirmation model in web-based services. Electronic Commerce Research and Applications, 10(3), 342-357.

Lee, Y.W., Strong, D.M., Kahn, B.K., \& Wang, R.Y. (2002). AIMQ: a methodology for information quality assessment. Information \& management, 40(2), 133-146.

Liao, C., Chen, J.-L., \& Yen, D.C. (2007). Theory of planning behavior (TPB) and customer satisfaction in the continued use of e-service: An integrated model. Computers in Human Behavior, 23(6), 2804-2822.

Limayem, M., \& Cheung, C.M. (2008). Understanding information systems continuance: The case of Internet-based learning technologies. Information \& management, 45(4), 227232.

Lin, C.-C., Wu, H.-Y., \& Chang, Y.-F. (2011). The critical factors impact on online customer satisfaction. Procedia Computer Science, 3, 276-281.

Lin, C.S., Wu, S., \& Tsai, R.J. (2005). Integrating perceived playfulness into expectationconfirmation model for web portal context. Information \& management, 42(5), 683693.

Lin, L.C.S. (2016). Convergence in election campaigns:The frame contest between Facebook and mass media. Convergence, 22(2), 199-214.

Little, R.J.A. (1988). Missing-Data Adjustments in Large Surveys. Journal of Business \& Economic Statistics, 6(3), 287-296.

Liu, A.H., Leach, M.P., \& Bernhardt, K.L. (2005). Examining customer value perceptions of organizational buyers when sourcing from multiple vendors. Journal of Business Research, 58(5), 559-568.

Lohmoller, J.-B. (1988). The PLS program system: Latent variables path analysis with partial least squares estimation. Multivariate Behavioral Research, 23(1), 125-127.

Menachemi, N. (2011). Assessing response bias in a web survey at a university faculty. Evaluation \& Research in Education, 24(1), 5-15.

Mihaila, G.A., Raschid, L., \& Vidal, M.-E. (2000). Using Quality of Data Metadata for Source Selection and Ranking. In WebDB (Informal Proceedings) (pp. 93-98): Citeseer. 
Millard, J. (2010). Government 1.5-is the bottle half full or half empty. European Journal of ePractice, 9(1), 35-50.

Monge, A.E. (2000). Matching algorithms within a duplicate detection system. IEEE Data Eng. Bull., 23(4), 14-20.

Muhammad, Z., Yi, F., Naz, A.S., \& Muhammad, K. (2014). An Empirical Study on Exploring Relationship among Information Quality, E-satisfaction, E-trust and Young Generation's Commitment to Chinese Online Retailing. Journal of Competitiveness, 6(4), 3-18.

Naumann, F., Leser, U., \& Freytag, J.C. (1999). Quality-driven integration of heterogeneous information systems. In 25th Conference on Very Large Database Systems (VLDB). (pp. 447-458).

Nitschke, P., Donges, P., \& Schade, H. (2016). Political organizations' use of websites and Facebook. New Media \& Society, 18(5), 744-764.

Oliver, R.L. (1980). A cognitive model of the antecedents and consequences of satisfaction decisions. Journal of marketing research, 7(11), 460-469.

Oliver, R.L. (2010). Satisfaction: A behavioral perspective on the consumer: ME sharpe.

Olsen, L.L., \& Johnson, M.D. (2003). Service equity, satisfaction, and loyalty: from transaction-specific to cumulative evaluations. Journal of Service Research, 5(3), 184-195.

Orgeron, C.P., \& Goodman, D. (2011). Evaluating citizen adoption and satisfaction of egovernment. IGI Global.

Papadomichelaki, X., \& Mentzas, G. (2012). e-GovQual: A multiple-item scale for assessing e-government service quality. Government Information Quarterly, 29(1), 98-109.

Podsakoff, P.M., MacKenzie, S.B., Lee, J.-Y., \& Podsakoff, N.P. (2003). Common method biases in behavioral research: a critical review of the literature and recommended remedies. Journal of applied psychology, 88(5), 879-903.

Podsakoff, P.M., \& Organ, D.W. (1986). Self-reports in organizational research: Problems and prospects. Journal of management, 12(4), 531-544.

Reddick, C.G., Abdelsalam, H.M.E., \& Elkadi, H.A. (2012). Channel choice and the digital divide in e-government: the case of Egypt. Information Technology for Development, 18(3), 226-246.

Reddick, C.G., Chatfield, A.T., \& Ojo, A. (In Press). A social media text analytics framework for double-loop learning for citizen-centric public services: A case study of a local government Facebook use. Government Information Quarterly.

Rieder, B., Abdulla, R., Poell, T., Woltering, R., \& Zack, L. (2015). Data critique and analytical opportunities for very large Facebook Pages: Lessons learned from exploring "We are all Khaled Said". Big Data \& Society, 2(2), 2053951715614980.

Ringle, C.M., Wende, S., \& Becker, J.-M. (2014). Smartpls 3. Hamburg: SmartPLS. In.

Roca, J.C., Chiu, C.-M., \& Martínez, F.J. (2006). Understanding e-learning continuance intention: An extension of the Technology Acceptance Model. International Journal of Human-Computer Studies, 64(8), 683-696.

Rodríguez Bolívar, M.P., Alcaide Muñoz, L., \& López Hernández, A.M. (2016). Scientometric Study of the Progress and Development of e-Government Research During the Period 2000-2012. Information Technology for Development, 22(1), 1-39.

Rogers, E.M. (2010). Diffusion of innovations: Simon and Schuster.

Sarstedt, M. (2008). A Review of Recent Approaches for Capturing Heterogeneity in Partial Least Squares Path Modelling. Journal of Modelling in Management, 3(2), 140-161.

Sarstedt, M., Henseler, J., \& Ringle, C.M. (2011). Multigroup analysis in partial least squares (PLS) path modeling: Alternative methods and empirical results. Advances in International Marketing, 22(1), 195-218. 
Shi, N., Lee, M.K., Cheung, C., \& Chen, H. (2010). The continuance of online social networks: how to keep people using Facebook? In System Sciences (HICSS), 2010 43rd Hawaii International Conference on (pp. 1-10): IEEE.

Soon, C., \& Soh, Y.D. (2014). Engagement@web 2.0 between the government and citizens in Singapore: dialogic communication on Facebook? Asian Journal of Communication, 24(1), 42-59.

Soper, D. (2015). A-priori sample size calculator for Structural Equation Models [Software]. In.

Stone, M. (1974). Cross-validatory choice and assessment of statistical predictions. Journal of the Royal Statistical Society. Series B (Methodological), 111-147.

Stone, R.W., \& Baker-Eveleth, L. (2013). Students' expectation, confirmation, and continuance intention to use electronic textbooks. Computers in Human Behavior, 29(3), 984-990.

Tabachnick, B.G., \& Fidell, L.S. (2013). Using multivariate statistics: Allyn and Bacon: Boston, MA.

Tampere, P., Tampere, K., \& Luoma-Aho, V. (2016). Facebook discussion of a crisis: authority communication and its relationship to citizens. Corporate Communications: An International Journal, 21(4), 414-434.

Teo, T.S., Srivastava, S.C., \& Jiang, L. (2008). Trust and electronic government success: An empirical study. Journal of Management Information Systems, 25(3), 99-132.

Thong, J.Y., Hong, S.-J., \& Tam, K.Y. (2006). The effects of post-adoption beliefs on the expectation-confirmation model for information technology continuance. International Journal of Human-Computer Studies, 64(9), 799-810.

Thornton, R.A. (2010). Texas State Agency Websites: A Descriptive Assessment of Attributes that Support Online Citizen Engagement. Texas State University-San Marcos.

Turel, O., \& Serenko, A. (2006). Satisfaction with mobile services in Canada: An empirical investigation. Telecommunications Policy, 30(5), 314-331.

Valaei, N. (2017). Organizational structure, sense making activities and SMEs' competitiveness: An application of confirmatory tetrad analysis-partial least squares (CTA-PLS). VINE Journal of Information and Knowledge Management Systems, 47(1), 16-41.

Valaei, N., \& Jiroudi, S. (2016). Job satisfaction and job performance in the media industry: a synergistic application of partial least squares path modelling. Asia Pacific Journal of Marketing and Logistics, 28(5), 984-1014.

Valaei, N., Rezaei, S., \& Ismail, W.K.W. (2017). Examining learning strategies, creativity, and innovation at SMEs using fuzzy set Qualitative Comparative Analysis and PLS path modeling. Journal of Business Research, 70, 224-233.

Vatanasombut, B., Igbaria, M., Stylianou, A.C., \& Rodgers, W. (2008). Information systems continuance intention of web-based applications customers: The case of online banking. Information \& management, 45(7), 419-428.

Wang, D., Xu, L., \& Chan, H.C. (2015). Understanding the continuance use of social network sites: a computer self-efficacy perspective. Behaviour \& Information Technology, 34(2), 204-216.

Wang, Y., \& Lo, H.-P. (2002). Service quality, customer satisfaction and behavior intentions: Evidence from China's telecommunication industry. info, 4(6), 50-60.

Weerakkody, V., Irani, Z., Lee, H., Hindi, N., \& Osman, I. (2014). A Review of the Factors Affecting User Satisfaction in Electronic Government Services. International Journal of Electronic Government Research (IJEGR), 10(4), 21-56. 
Wilson, B., \& Henseler, J. (2007). Modeling reflective higher-order constructs using three approaches with PLS path modeling: a Monte Carlo comparison. In Australian and New Zealand Marketing Academy Conference (pp. 791-800).

Wilson, R.E., Gosling, S.D., \& Graham, L.T. (2012). A review of Facebook research in the social sciences. Perspectives on psychological science, 7(3), 203-220.

Wu, J., Tsai, R.J., Chen, C.C., \& Wu, Y. (2006). An integrative model to predict the continuance use of electronic learning systems: hints for teaching. International Journal on E-Learning, 5(2), 287-302.

Ye, L., \& Ki, E.-J. (2017). Organizational crisis communication on Facebook: A study of BP's Deepwater Horizon oil spill. Corporate Communications: An International Journal, 22(1), 80-92.

Yi, Y., \& La, S. (2004). What influences the relationship between customer satisfaction and repurchase intention? Investigating the effects of adjusted expectations and customer loyalty. Psychology \& Marketing, 21(5), 351-373.

Zeithaml, V.A., Berry, L.L., \& Parasuraman, A. (1996). The behavioral consequences of service quality. the Journal of Marketing, 31-46. 
Acknowledgements

Acknowledgement: This work was supported by the Government of Malaysia (Py/2014/2028); Universiti Teknologi Malaysia under grant; RMC Cost Center: Q.K130000.2563.05H81; RMC Reference Number: PY/2014/02028 


\section{List of Tables}

Table 1: Sample Characteristics $(\mathrm{N}=362)$

\begin{tabular}{cccc}
\hline & Characteristics & Frequency & Percent \\
\hline Gender & Male & 128 & 35.4 \\
& Female & 234 & 64.6 \\
Age & $20-29$ & 230 & 63.5 \\
& $30-39$ & 110 & 30.4 \\
& $40-49$ & 20 & 5.5 \\
& $50-59$ & 2 & 0.6 \\
Ethnicity & & & \\
& Malay & 242 & 66.9 \\
& Chinese & 64 & 17.7 \\
& Indian & 50 & 13.8 \\
& Others & 6 & 1.7 \\
& & & \\
& JPJ & 47 & 13 \\
& Jobs & 35 & 9.7 \\
& KPM & 78 & 21.5 \\
& KWSP & 21 & 5.8 \\
& LTH & 20 & 5.5 \\
& SPA & 52 & 14.4 \\
& RMP & 51 & 14.1 \\
& PDRM & 48 & 13.3 \\
& Others & 10 & 2.8 \\
& & & \\
& Diploma & 10 & 2.8 \\
& Bachelor & 278 & 76.8 \\
& Master & 66 & 18.2 \\
& & 8 & 2.2 \\
\hline
\end{tabular}

Table2: Goodness of model fit

\begin{tabular}{lll}
\hline Fit criteria & Value & HI95 \\
\hline SRMR & 0.040 & 0.042 \\
$\mathbf{d}_{\text {ULS }}$ & 0.526 & 0.579 \\
$\mathbf{d}_{\mathbf{G}}$ & 0.607 & 0.732 \\
\hline
\end{tabular}

Notes: HI95 $=95 \%$ of bootstrap quantile.

Model assessment criteria: SRMR < 95\% of bootstrap quantile (HI95 of SRMR), $\mathrm{d}_{\mathrm{ULS}}<95 \%$ of bootstrap quantile (HI95 of $\mathrm{d}_{\mathrm{ULS}}$ ), and $\mathrm{d}_{\mathrm{G}}<95 \%$ of bootstrap quantile (HI95 of $\left.d_{G}\right)$. 
Table 3: Construct validity

\begin{tabular}{|c|c|c|c|c|c|c|c|}
\hline Constructs & First order constructs & Item & $\begin{array}{c}\text { Item } \\
\text { Loading }\end{array}$ & $\boldsymbol{\rho A}$ & $\mathbf{A V E}^{\mathbf{a}}$ & $\begin{array}{l}\text { Composite } \\
\text { Reliability }^{\text {b }}\end{array}$ & $\begin{array}{c}\text { Cronbach } \\
\text { Alpha }\end{array}$ \\
\hline \multirow[t]{18}{*}{ Information quality } & Reliability & RLA1 & 0.930 & 0.934 & 0.835 & 0.953 & 0.934 \\
\hline & & RLA2 & 0.915 & & & & \\
\hline & & RLA3 & 0.925 & & & & \\
\hline & & RLA4 & 0.883 & & & & \\
\hline & Completeness & CPN1 & 0.830 & 0.887 & 0.745 & 0.921 & 0.886 \\
\hline & & CPN2 & 0.882 & & & & \\
\hline & & CPN3 & 0.890 & & & & \\
\hline & & CPN4 & 0.850 & & & & \\
\hline & Relevancy & RLV1 & 0.928 & 0.935 & 0.883 & 0.958 & 0.934 \\
\hline & & RLV2 & 0.952 & & & & \\
\hline & & RLV3 & 0.939 & & & & \\
\hline & Understandable & UA1 & 0.910 & 0.949 & 0.866 & 0.963 & 0.949 \\
\hline & & UA2 & 0.940 & & & & \\
\hline & & UA3 & 0.941 & & & & \\
\hline & & UA4 & 0.932 & & & & \\
\hline & Timeliness & TL1 & 0.935 & 0.930 & 0.877 & 0.955 & 0.930 \\
\hline & & TL2 & 0.939 & & & & \\
\hline & & TL3 & 0.935 & & & & \\
\hline \multirow{4}{*}{$\begin{array}{l}\text { Satisfaction of government's } \\
\text { Facebook page }\end{array}$} & & SatFB 1 & 0.922 & 0.944 & 0.854 & 0.959 & 0.943 \\
\hline & & SatFB2 & 0.928 & & & & \\
\hline & & SatFB3 & 0.943 & & & & \\
\hline & & SatFB4 & 0.904 & & & & \\
\hline \multirow{3}{*}{$\begin{array}{l}\text { Continuance intention of } \\
\text { following Facebook page }\end{array}$} & & CIFB1 & 0.894 & 0.905 & 0.840 & 0.940 & 0.905 \\
\hline & & CIFB2 & 0.944 & & & & \\
\hline & & CIFB3 & 0.912 & & & & \\
\hline
\end{tabular}

Notes: a. Average variance extracted $(\mathrm{AVE})=($ summation of the square of the factor loadings $) /[$ (summation of the square of the factor loadings $)+($ summation of the error variances)] b. Composite reliability $(\mathrm{CR})=$ (square of the summation of the factor loadings)/[(square of the summation of the factor loadings) + (square of the summation of the error variances)]

Table 4a: Discriminant validity- Fornell-Larcker criterion

\begin{tabular}{cccccccc}
\hline Constructs & CPN & CIFB & RLV & RLA & SatFB & TL & UA \\
\hline CPN & $\mathbf{0 . 8 6 3}^{\mathbf{a}}$ & & & & & & \\
CIFB & 0.597 & $\mathbf{0 . 9 1 7}$ & & & & & \\
RLV & 0.574 & 0.524 & $\mathbf{0 . 9 4 0}$ & & & & \\
RLA & 0.614 & 0.605 & 0.524 & $\mathbf{0 . 9 1 4}$ & & & \\
SatFB & 0.652 & 0.760 & 0.592 & 0.577 & $\mathbf{0 . 9 2 4}$ & & \\
TL & 0.499 & 0.600 & 0.615 & 0.638 & 0.632 & $\mathbf{0 . 9 3 6}$ & \\
UA & 0.675 & 0.709 & 0.555 & 0.639 & 0.771 & 0.665 & $\mathbf{0 . 9 3 1}$
\end{tabular}

Note: a. The off-diagonal are the correlations between the latent constructs and diagonals are square values of AVEs. b. Completeness (CPN), Continuance intention of following Facebook page (CIFB), Relevancy (RLV), Reliability (RLA), Satisfaction of government's Facebook page (SatFB), Timeliness (TL), and Understandable (UA). 
Table 4b: Discriminant validity- Cross loadings

\begin{tabular}{|c|c|c|c|c|c|c|c|}
\hline Items & CPN & CIFB & RLV & RLA & SatFB & TL & UA \\
\hline CIFB1 & 0.594 & 0.894 & 0.526 & 0.578 & 0.690 & 0.571 & 0.676 \\
\hline CIFB2 & 0.522 & 0.944 & 0.456 & 0.525 & 0.696 & 0.566 & 0.630 \\
\hline CIFB3 & 0.525 & 0.912 & 0.456 & 0.559 & 0.704 & 0.512 & 0.641 \\
\hline CPN1 & 0.830 & 0.515 & 0.523 & 0.524 & 0.548 & 0.461 & 0.493 \\
\hline CPN2 & 0.882 & 0.478 & 0.478 & 0.519 & 0.571 & 0.418 & 0.545 \\
\hline CPN3 & 0.890 & 0.565 & 0.522 & 0.575 & 0.576 & 0.444 & 0.639 \\
\hline CPN4 & 0.850 & 0.501 & 0.459 & 0.498 & 0.555 & 0.401 & 0.647 \\
\hline RLA1 & 0.574 & 0.559 & 0.449 & 0.930 & 0.556 & 0.579 & 0.583 \\
\hline RLA2 & 0.568 & 0.529 & 0.502 & 0.915 & 0.532 & 0.564 & 0.544 \\
\hline RLA3 & 0.548 & 0.560 & 0.459 & 0.925 & 0.523 & 0.607 & 0.598 \\
\hline RLA4 & 0.551 & 0.563 & 0.505 & 0.883 & 0.497 & 0.580 & 0.609 \\
\hline UA1 & 0.612 & 0.647 & 0.496 & 0.582 & 0.709 & 0.590 & 0.910 \\
\hline UA2 & 0.628 & 0.639 & 0.527 & 0.617 & 0.693 & 0.626 & 0.940 \\
\hline UA3 & 0.634 & 0.683 & 0.538 & 0.602 & 0.733 & 0.624 & 0.941 \\
\hline UA4 & 0.639 & 0.670 & 0.505 & 0.578 & 0.737 & 0.637 & 0.932 \\
\hline SatFB1 & 0.597 & 0.679 & 0.527 & 0.578 & 0.922 & 0.602 & 0.725 \\
\hline SatFB2 & 0.579 & 0.686 & 0.498 & 0.485 & 0.928 & 0.524 & 0.694 \\
\hline SatFB3 & 0.607 & 0.759 & 0.579 & 0.523 & 0.943 & 0.593 & 0.712 \\
\hline SatFB4 & 0.627 & 0.684 & 0.581 & 0.547 & 0.904 & 0.617 & 0.720 \\
\hline RLV1 & 0.509 & 0.486 & 0.928 & 0.468 & 0.556 & 0.584 & 0.472 \\
\hline RLV2 & 0.541 & 0.516 & 0.952 & 0.511 & 0.572 & 0.575 & 0.551 \\
\hline RLV3 & 0.567 & 0.475 & 0.939 & 0.497 & 0.542 & 0.576 & 0.538 \\
\hline TL1 & 0.479 & 0.577 & 0.604 & 0.608 & 0.616 & 0.935 & 0.658 \\
\hline TL2 & 0.445 & 0.531 & 0.542 & 0.582 & 0.568 & 0.939 & 0.606 \\
\hline TL3 & 0.476 & 0.576 & 0.580 & 0.601 & 0.591 & 0.935 & 0.603 \\
\hline
\end{tabular}

Note: Completeness (CPN), Continuance intention of following Facebook page (CIFB), Relevancy (RLV), Reliability (RLA), Satisfaction of government's Facebook page (SatFB), Timeliness (TL), and Understandable (UA).

Table 4c: Discriminant validity- Heterotrait-Monotrait ratio

\begin{tabular}{|c|c|c|c|c|c|c|}
\hline & $\mathbf{C P N}$ & CIFB & RLV & RLA & SatFB & TL \\
\hline CIFB & $0.666_{[\mathrm{CI}, 0.579: 0.743]}^{\mathbf{a}}$ & & & & & \\
\hline RLV & $0.631_{[\mathrm{CI}, 0.553: 0.702]}$ & $0.569_{[\mathrm{CI}, 0.473: 0.652]}$ & & & & \\
\hline RLA & $0.674_{[\mathrm{CI}, 0.599: 0.740]}$ & $0.658_{[\mathrm{CI}, 0.558: 0.734]}$ & $0.561_{[\mathrm{CI}, 0.482: 0.635]}$ & & & \\
\hline SatFB & $0.713_{[\mathrm{CI}, 0.640: 0.772]}$ & $0.822_{[\mathrm{CI}, 0.764: 0.873]}$ & $0.630_{[\mathrm{CI}, 0.556: 0.694]}$ & $0.615_{[\mathrm{CI}, 0.518: 0.690]}$ & & \\
\hline $\mathrm{TL}$ & $0.550_{[\mathrm{CI}, 0.442: 0.638]}$ & $0.653_{[\mathrm{CI}, 0.573: 0.725]}$ & $0.660_{[\mathrm{CI}, 0.583: 0.729]}$ & $0.684_{[\mathrm{CI}, 0.618: 0.742]}$ & $0.674_{[\mathrm{CI}, 0.604: 0.740]}$ & \\
\hline UA & $0.735_{[\mathrm{CI}, 0.649: 0.805]}$ & $0.764_{[\mathrm{CI}, 0.702: 0.819]}$ & $0.589_{[\mathrm{CI}, 0.501: 0.667]}$ & $0.679_{[\mathrm{CI}, 0.600: 0.744]}$ & $0.815_{[\mathrm{CI}, 0.767: 0.853]}$ & $0.708_{[\mathrm{CI}, 0.638: 0.764]}$ \\
\hline
\end{tabular}

Notes: a. The criterion for Heterotrait-Monotrait ratio is below 0.90 (Gold \& Arvind Malhotra, 2001;

Teo, Srivastava, \& Jiang, 2008). b. The criterion for HTMT upper confidence intervals (CI) is below 1

(Henseler, Ringle, \& Sarstedt, 2015). Completeness (CPN), Continuance intention of following

Facebook page (CIFB), Relevancy (RLV), Reliability (RLA), Satisfaction of government's Facebook page (SatFB), Timeliness (TL), and Understandable (UA). 
Table 5: Weights of first-orders on information quality second-order construct (Examining H1)

\begin{tabular}{|c|c|c|c|c|c|}
\hline Second order construct & First order constructs & Beta & $\begin{array}{c}\mathrm{t}- \\
\text { Statistics }\end{array}$ & AVE & CR \\
\hline \multirow[t]{5}{*}{ Information quality } & Reliability & 0.838 & $47.106^{*}$ & 0.679 & 0.914 \\
\hline & Completeness & 0.818 & $36.815^{*}$ & & \\
\hline & Relevancy & 0.767 & $32.209 *$ & & \\
\hline & Understandable & 0.877 & $57.642 *$ & & \\
\hline & Timeliness & 0.817 & $38.870^{*}$ & & \\
\hline
\end{tabular}

Note: $* 2.57(1 \%$ significant level)

Table 6: Hypothesis Testing (Direct effect)

\begin{tabular}{cccccc}
\hline Hypothesis & Path & Path & Standard & T-value & Decision \\
& & & Coefficient & Error & \\
\hline H2 & Information Quality -> Continuance Intention of following FB Page & 0.378 & 0.067 & $5.648^{*}$ & Supported \\
H3 & Information Quality -> Satisfaction of Government's FB Page & 0.787 & 0.021 & $36.897 *$ & Supported \\
H4 & Satisfaction of Government's FB Page -> Continuance Intention & 0.463 & 0.069 & $6.743 *$ & Supported \\
& & of following FB Page & & & \\
\hline
\end{tabular}

$* \mathrm{P}<0.01$

Table 7: Mediation analysis for satisfaction of government FB page (Examining H5)

\begin{tabular}{|c|c|c|c|c|}
\hline Relationship & Path coefficient & T-value & & P-value \\
\hline IQ -> CI of government FB page & 0.743 & 25.600 & & 0.000 \\
\hline IQ -> satisfaction of government FB page & 0.787 & 36.897 & & 0.000 \\
\hline Satisfaction of government FB page $->\mathrm{CI}$ & 0.463 & 6.743 & & 0.000 \\
\hline & Standard error & T-value & VAF & Decision \\
\hline $\begin{array}{l}\text { H5: IQ }->\text { satisfaction of government FB } \\
\text { page }->\text { CI of government FB page }\end{array}$ & 0.054 & $6.748 *$ & $50 \%$ & Supported \\
\hline
\end{tabular}

Notes: Variance accounted for (VAF), ${ }^{*} \mathrm{p}<0.01$ 
Table 8a: Structural relationship and hypothesis testing across different Facebook Pages (Examining H6 through PLS-MGA)

\begin{tabular}{|c|c|c|c|c|c|c|c|c|c|c|c|c|c|c|}
\hline \multirow{2}{*}{$\begin{array}{c}\text { Path } \\
\text { IQ -> }\end{array}$} & \multicolumn{7}{|c|}{ Path Coefficients' Differences } & \multicolumn{7}{|c|}{ P-Values } \\
\hline & $1 \mathrm{Vs} .2^{\mathrm{a}}$ & 1vs.3 & 1vs.4 & 1vs.5 & 1vs.6 & 1vs.7 & 1vs.8 & 1vs.2 & 1vs.3 & 1vs.4 & $1 \mathrm{vs.5}$ & 1vs.6 & 1vs.7 & 1vs.8 \\
\hline & 0.315 & 0.653 & 0.33 & 0.445 & 0.292 & 0.369 & 0.338 & 0.942 & $0.960^{b}$ & 0.876 & 0.963 & 0.900 & 0.939 & 0.868 \\
\hline & 3vs.5 & 3vs.6 & 3vs.7 & 3vs.8 & 4vs.5 & 4vs.6 & 4vs.7 & 3vs.5 & 3vs.6 & 3vs.7 & 3vs.8 & 4vs.5 & 4vs.6 & 4vs.7 \\
\hline & 0.284 & 0.115 & 0.038 & 0.039 & 0.153 & 0.076 & 0.077 & 0.191 & 0.641 & 0.426 & 0.534 & 0.247 & 0.376 & 0.632 \\
\hline
\end{tabular}

Notes: a. 1=JPJ; 2=Jobs Malaysia; 3=KPM; 4=KWSP; 5=LTH; 6=PDRM; 7=RMP; and 8=SPA.

b. $\mathrm{P}$-values below 0.05 and higher than 0.95 indicate significant values (Henseler, Ringle, \& Sinkovics, 2009).

Table 8b: Structural relationship and hypothesis testing across different Facebook Pages (Examining H6 through PLS-MGA)

\begin{tabular}{ccccccccc|cccccc}
\hline Path & \multicolumn{10}{c}{ Path Coefficients' Differences } & \multicolumn{4}{c}{ P-Values } \\
\hline IQ -> Different & $\mathbf{1 v s . 2}^{\text {a }}$ & $\mathbf{1 v s . 3}$ & $\mathbf{1 v s . 4}$ & $\mathbf{1 v s . 5}$ & $\mathbf{1 v s . 6}$ & $\mathbf{1 v s . 7}$ & $\mathbf{1 v s . 8}$ & $\mathbf{1 v s . 2}$ & $\mathbf{1 v s . 3}$ & $\mathbf{1 v s . 4}$ & $\mathbf{1 v s . 5}$ & $\mathbf{1 v s . 6}$ & $\mathbf{1 v s . 7}$ & $\mathbf{1 v s . 8}$ \\
FB Pages -> & 0.005 & 0.139 & 0.024 & 0.044 & 0.198 & 0.048 & 0.007 & 0.517 & $\mathbf{0 . 0 4 9}$ & 0.426 & 0.343 & $\mathbf{0 . 0 2 3}$ & 0.273 & 0.517 \\
SatFB & $\mathbf{2 v s . 3}$ & $\mathbf{2 v s . 4}$ & $\mathbf{2 v s . 5}$ & $\mathbf{2 v s . 6}$ & $\mathbf{2 v s . 7}$ & $\mathbf{2 v s . 8}$ & $\mathbf{3 v s . 4}$ & $\mathbf{2 v s . 3}$ & $\mathbf{2 v s . 4}$ & $\mathbf{2 v s . 5}$ & $\mathbf{2 v s . 6}$ & $\mathbf{2 v s . 7}$ & $\mathbf{2 v s . 8}$ & $\mathbf{3 v s . 4}$ \\
& 0.145 & 0.029 & 0.05 & 0.203 & 0.054 & 0.002 & 0.116 & $\mathbf{0 . 0 3 1}$ & 0.397 & 0.313 & $\mathbf{0 . 0 1 3}$ & 0.246 & 0.500 & 0.901 \\
& $\mathbf{3 v s . 5}$ & $\mathbf{3 v s . 6}$ & $\mathbf{3 v s . 7}$ & $\mathbf{3 v s . 8}$ & $\mathbf{4 v s . 5}$ & $\mathbf{4 v s . 6}$ & $\mathbf{4 v s . 7}$ & $\mathbf{3 v s . 5}$ & $\mathbf{3 v s . 6}$ & $\mathbf{3 v s . 7}$ & $\mathbf{3 v s . 8}$ & $\mathbf{4 v s . 5}$ & $\mathbf{4 v s . 6}$ & $\mathbf{4 v s . 7}$ \\
& 0.095 & 0.058 & 0.091 & 0.146 & 0.021 & 0.174 & 0.025 & 0.838 & 0.245 & 0.876 & $\mathbf{0 . 9 7 6}$ & 0.430 & 0.056 & 0.377 \\
& $\mathbf{4 . v s 8}$ & $\mathbf{5 v s . 6}$ & $\mathbf{5 v s . 7}$ & $\mathbf{5 v s . 8}$ & $\mathbf{6 v s . 7}$ & $\mathbf{6 v s . 8}$ & $\mathbf{7 v s . 8}$ & $\mathbf{4 . v s 8}$ & $\mathbf{5 v s . 6}$ & $\mathbf{5 v s . 7}$ & $\mathbf{5 v s . 8}$ & $\mathbf{6 v s . 7}$ & $\mathbf{6 v s . 8}$ & $\mathbf{7 v s . 8}$ \\
& 0.031 & 0.153 & 0.004 & 0.052 & 0.149 & 0.205 & 0.056 & 0.615 & 0.081 & 0.456 & 0.695 & $\mathbf{0 . 9 5 5}$ & $\mathbf{0 . 9 9 5}$ & 0.784 \\
\hline
\end{tabular}

Notes: a. 1=JPJ; 2=Jobs Malaysia; 3=KPM; 4=KWSP; 5=LTH; 6=PDRM; 7=RMP; and 8=SPA.

b. P-values below 0.05 and higher than 0.95 indicate significant values (Henseler, et al., 2009).

Table 8c: Structural relationship and hypothesis testing across different Facebook Pages (Examining H6 through PLS-MGA)

\begin{tabular}{|c|c|c|c|c|c|c|c|c|c|c|c|c|c|c|}
\hline \multirow{2}{*}{$\begin{array}{c}\text { Path } \\
\text { SatFB -> }\end{array}$} & \multicolumn{7}{|c|}{ Path Coefficients' Differences } & \multicolumn{7}{|c|}{ P-Values } \\
\hline & $1 \mathrm{vs} .2^{\mathrm{a}}$ & 1vs.3 & 1vs.4 & $1 \mathrm{vs.5}$ & 1 vs.6 & 1vs.7 & 1vs.8 & 1vs.2 & 1vs.3 & $1 \mathrm{vs.4}$ & $1 \mathrm{vs.5}$ & $1 \mathrm{vss.6}$ & 1vs.7 & 1vs.8 \\
\hline $\begin{array}{c}\text { Different FB } \\
\text { Pages -> }\end{array}$ & 0.484 & 0.07 & 0.441 & 0.2 & 0.152 & 0.14 & 0.052 & $0.978^{b}$ & 0.630 & 0.126 & 0.760 & 0.261 & 0.724 & 0.580 \\
\hline CIFB & $2 \mathrm{vs.3}$ & $2 \mathrm{vs.4}$ & $2 \mathrm{vs.5}$ & 2vs.6 & 2vs.7 & $2 \mathrm{vs.8}$ & $3 v s .4$ & $2 \mathrm{vs.3}$ & $2 \mathrm{vs.4}$ & $2 \mathrm{vs.5}$ & $2 \mathrm{vs.6}$ & $2 \mathrm{vs.} 7$ & $2 \mathrm{vs.8}$ & $3 v s .4$ \\
\hline & 0.414 & 0.925 & 0.284 & 0.636 & 0.344 & 0.432 & 0.511 & 0.017 & 0.013 & 0.141 & 0.003 & 0.061 & 0.026 & 0.086 \\
\hline & $3 v s .5$ & 3vs.6 & 3vs.7 & 3vs.8 & 4vs.5 & 4vs.6 & 4vs.7 & 3vs.5 & 3vs.6 & 3vs.7 & 3vs.8 & $4 \mathrm{vs.5}$ & 4vs.6 & 4vs.7 \\
\hline & 0.129 & 0.222 & 0.07 & 0.019 & 0.64 & 0.289 & 0.581 & 0.686 & 0.153 & 0.632 & 0.462 & 0.935 & 0.784 & 0.925 \\
\hline & 4.vs8 & 5vs.6 & 5vs.7 & $5 \mathrm{vs.8}$ & 6vs.7 & 6vs.8 & 7vs.8 & 4.vs8 & 5vs.6 & 5vs.7 & $5 \mathrm{vs.8}$ & 6vs.7 & $6 \mathrm{vs.8}$ & 7vs.8 \\
\hline & 0.492 & 0.352 & 0.06 & 0.148 & 0.292 & 0.203 & 0.088 & 0.894 & 0.352 & 0.060 & 0.148 & 0.897 & 0.814 & 0.347 \\
\hline
\end{tabular}

Notes: a. 1=JPJ; 2=Jobs Malaysia; 3=KPM; 4=KWSP; 5=LTH; 6=PDRM; 7=RMP; and 8=SPA.

b. P-values below 0.05 and higher than 0.95 indicate significant values (Henseler, et al., 2009). 
Gold, A.H., \& Arvind Malhotra, A.H.S. (2001). Knowledge management: An organizational capabilities perspective. Journal of Management Information Systems, 18(1), 185-214.

Henseler, J., Ringle, C.M., \& Sarstedt, M. (2015). A new criterion for assessing discriminant validity in variance-based structural equation modeling. Journal of the Academy of Marketing Science, 43(1), 115-135.

Henseler, J., Ringle, C.M., \& Sinkovics, R.R. (2009). The use of partial least squares path modeling in international marketing. In New Challenges to International Marketing (pp. 277-319).

Teo, T.S., Srivastava, S.C., \& Jiang, L. (2008). Trust and electronic government success: An empirical study. Journal of Management Information Systems, 25(3), 99-132. 
Figure 1: Theoretical model

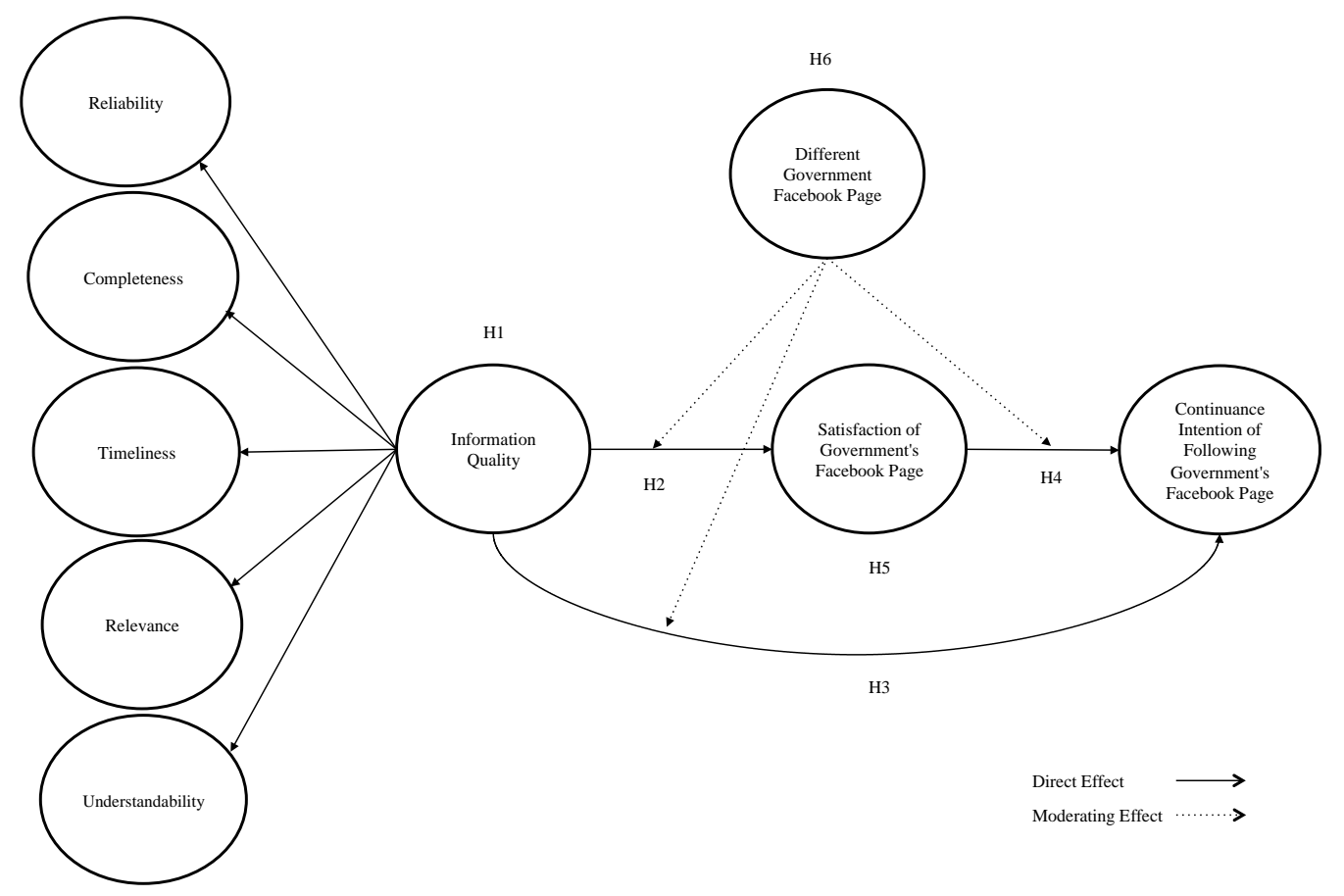

Figure 2: PLS results

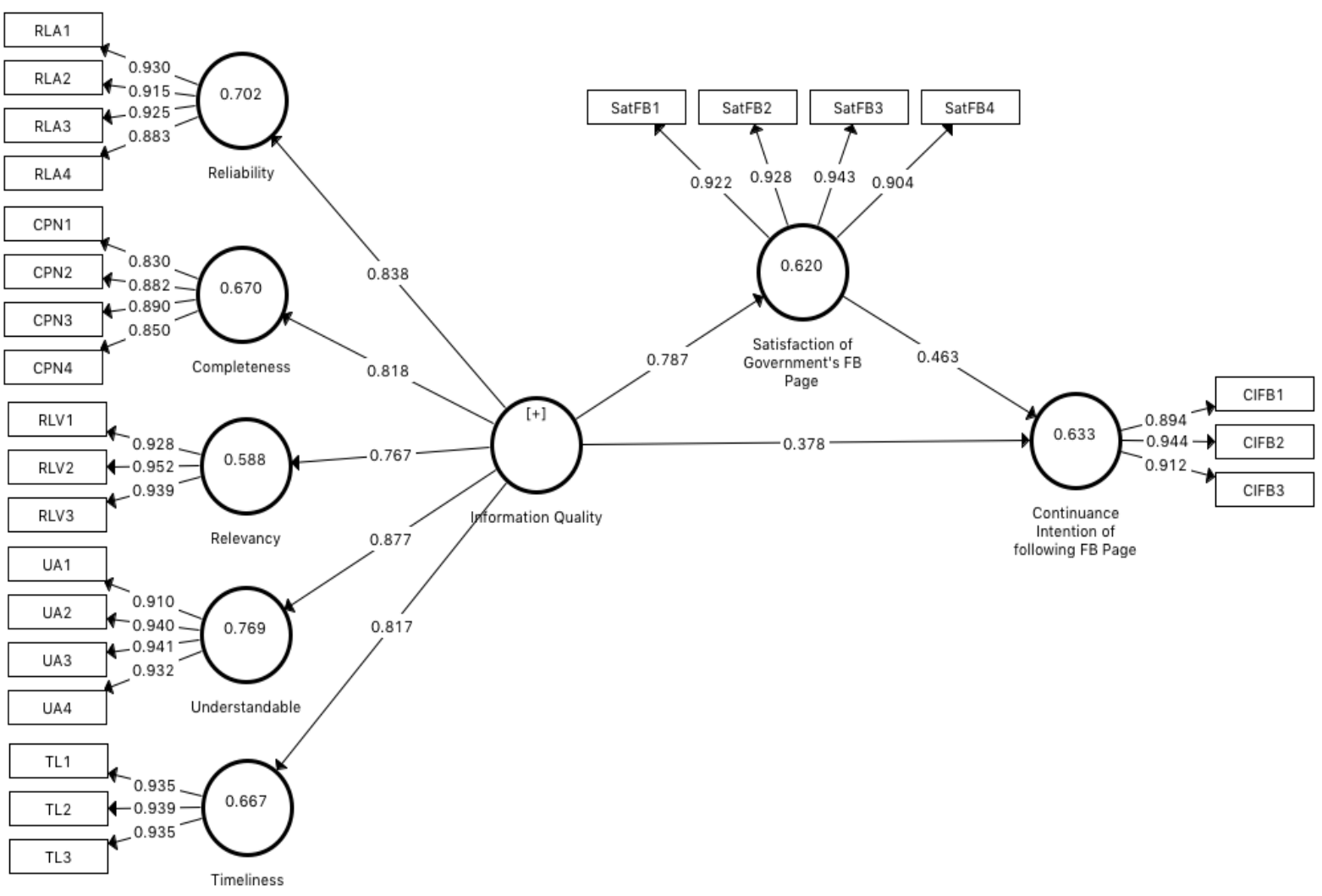

